\title{
Can Tax Incentives for Electronic Payments Curtail the Shadow Economy? Korea's Attempt to Reduce Underreporting in Retail Businesses*
}

\author{
Myung Jae Sung**, Rajul Awasthi*** and Hyung Chul Lee****
}

\begin{abstract}
Increasing tax revenues by curtailing the shadow economy has been a central goal of tax policy and administration in the Republic of Korea since the National Tax Service was established as an independent agency in 1966. This paper examines the Tax Incentives for Electronically Traceable Payments (TIETP) introduced by the Korean tax authorities in 1999 to promote payments made using credit cards, debit cards, and electronic cash receipts in business-to-consumer transactions. TIETP allows wage and salary earners to claim tax deductions for eligible purchases made using electronically traceable payments when they file their year-end income tax return. This tax incentive scheme has greatly contributed to transforming the Korean economy into a cashless economy over the last decade and a half. Card payments as a ratio of Korea's GDP have ranked highest in the world since 2005, reaching $49 \%$ in 2014 . TIETP has increased the percentage of business income earners who pay taxes from stagnant at around $30 \%$ up to the late 1990 s to approximately $80 \%$ at present. The effective personal income tax rate for business income followed a continuous upward trend from $3.4 \%$ in 1998 to $6.3 \%$ in 2013 . The total revenue increase driven by TIETP has been estimated as $\$ 3.4$ trillion, with TIETP costs reaching 1.9 trillion. The net gain is an estimated 1.4 trillion (approximately US $\$ 1.3$ billion), an increase of personal income tax revenue by $4.2 \%$. TIETP also had a positive impact on income redistribution, decreasing Gini coefficients by 0.11 percentage points.
\end{abstract}

Keywords: shadow economy, electronic payment, electronic tax administration, tax fraud, tax incentives.

*The authors have no financial arrangements that might give rise to conflicts of interest with respect to the research reported in this paper.

** Myung Jae Sung is a professor in the School of Economics, Hongik University, Seoul, South Korea. Email: mjaesung@hongik.ac.kr.

*** Rajul Awasthi works in the Worldbank's Tax Policy and Revenue Administration, Washington, DC, 20433. Email: rawasthi@worldbank.org.

**** Hyung Chul Lee works in the Ministry of Finance and Strategy, Sejong, South Korea. Email: hyungchul.lee66@gmail.com.

Manuscript received June 20, 2016; out for review June 27, 2017; review completed July 243, 2017; accepted August 4, 2017.

The Korean Journal of Policy Studies, Vol. 32, No. 2 (2017), pp. 85-134.

(C) 2017 by the GSPA, Seoul National University 


\section{INTRODUCTION}

This paper aims to evaluate the performance of the Tax Incentives for Electronically Traceable Payments (TIETP) in Korea, particularly in terms of the effects on tax revenue and income redistribution. It is widely believed that it has been successful in promoting tax compliance. However, this belief is based only on subjective inference and is not supported by any concrete evidence.

Tax administrations around the world are losing valuable tax revenues due to noncompliance by members of the shadow economy. According to some estimates, on average, one-third of the world economy is informally structured (see, for example, Schneider, Buehn, \& Montenegro 2010). Many consumers are all too familiar with the seductive temptation of buying goods without a bill or a receipt and saving on the value-added tax (or sales tax) that would otherwise be paid. It may not even cross the mind of a consumer who uses the services of a plumber or a carpenter and forks over the fees in cash that a VAT on the service rendered should have been added to the billed amount.

Cash has always been a facilitator of the shadow economy, since cash transactions do not leave an audit trail. Cash transactions between businesses and individual consumers are susceptible to falling prey to the shadow economy. Individuals are consumers of business goods and services, and if they purchase these goods and services in cash, they provide businesses with the opportunity not to report or to underreport those sales. However, consumers do not always have a reason to ask for invoices or receipts from businesses, since they ordinarily do not seek a tax credit for VAT or report it as an expense on their income tax return. Hence if business sellers offer customers prices lower than their competitors' on the condition of cash payment, customers are very likely to accept that offer. Authorities find it hard to detect and curb cash transactions of this sort, since sellers and buyers have no conflicting interests and provide no cross-checks.

In this context, measures to encourage businesses and consumers to pay their bills using banking channels or electronic forms of payment can and should be designed and implemented as a means of creating audit trails. There appears to be a strong negative relationship between use of electronic or formal payments and the size of the shadow economy. A study of the European economy by A. T. Kearney and Schneider confirms this association (2009). 
Figure 1. The Shadow Economy and Electronic Transactions

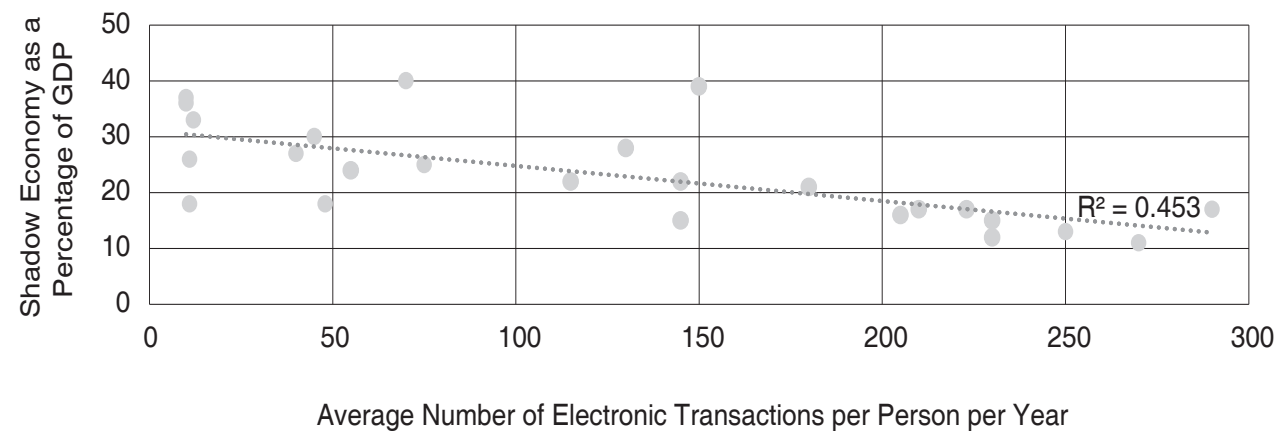

Source: Kearney \& Schneider (2009).

Many countries, therefore, are making concerted efforts to encourage the reporting of sales transactions and the use of formal payment systems and to discourage cash transactions. Adoption of tax measures - both in the realm of policy and administration - are required to incentivize formal payments for business transactions through banking channels, including electronic payments and the use of "plastic money." Tax policy and tax administration can be important components of a broader strategy to increase the level of cashless transactions; the tax system can either provide a stimulus for moving to noncash payment methods or it can discourage the use of cash. Of course, encouraging cashless transactions and promoting the use of banking channels is a holistic effort requiring the participation of several government agencies (from tax authorities to ministries of finance, from central banks to financial intelligence units).

To move successfully in the direction of a cashless economy requires the strong political will to adopt the necessary measures. Among the measures adopted by some countries to reduce the shadow economy are incentives for payments by electronic means, limitations on cash payments, limits on cash withdrawals from bank accounts for legal entities and individual businesspeople, partial exemptions from taxation turnover for businesses conducted in noncash form, restrictions on buying and selling operations for a single transaction or for a certain time period, mandatory use of point-of-sale terminals in the trade and service sectors, expansion in other economic sectors of obligatory use of cash registers with SIM cards, and so on. Arguments continue over the effectiveness of these various measures, but recent research supports the conclusion that these efforts, if backed by public outreach campaigns communicating the benefits of cashless transactions, can help promote the use of banking channels among citizens and businesses. 
Several countries around the globe have adopted specific tax measures to encourage reporting of business-to-consumer transactions and to promote cashless transactions and banking channels (Awasthi \& Engelschalk, forthcoming). For example, in Colombia, a 2\% VAT refund is available for individuals on purchases made by debit and credit card or electronic banking for products and services paid at the general $16 \%$ rate or at the 5\% rate. Argentina launched a VAT discount for debit card use at point of sale in 2001, giving cardholders a 5\% reduction in the basic VAT rate of $21 \%$ on all purchases under ARS\$1,000 (US\$220). In 2003, Argentina added credit cards to the policy, giving cardholders a $3 \%$ reduction on their purchases. The government also introduced a further $2 \%$ reduction on purchases of gasoline via debit or credit payments. Credit card rebates were abolished in 2009, but debit card rebates remain in force.

Countries in the European Union have established quantitative limits (the highest limit is $€ 12,700$ in the Czech Republic and the lowest is $€ 1,300$ in Denmark) on the amount of cash that can be used to purchase goods and services in one twenty-four hour period. The idea is that individuals will thus be forced to use electronic means of payments - such as credit, debit, and ATM cards - which necessarily go through the banking system and hence are far easier to track. Several other countries also have policies directly prohibiting the use of cash for business transactions over a certain limit. In Peru, payments exceeding S/.3,500 (US\$1,000) must be made via bank account deposits, wire transfers, payment orders, credit cards, nonnegotiable checks, or other means of payment as provided by entities of the Peruvian financial system. In Turkey, payments of amounts over TL8,000 and any rental payments over TL500 must be made through the banking system or postal office. The effectiveness of these limits at curbing cash transactions is not clear, however, and confirmation is lacking that transactions are not being split to avoid the limits on cash use.

Countries often mandate limits on the use of cash for expenses that qualify as business deductions. In Colombia, as of January 1, 2014, any expenses considered deductible for tax purposes have to be made through one of the following payment methods: deposits in bank accounts, bank transfers, checks, and credit or debit cards. ${ }^{1}$ Cash payments are fiscally deductible only if they are below a certain amount. In Mexico, allowable deductions of a company's expenditures must be backed by a digital tax receipt issued, and payments exceeding MXN\$2,000 must be made through electronic transfer of funds, by personal check or credit, debit, or service cards, or through an electronic pocketbook. In India, sections 40A (3) and (3A) of the Income

1. "Medios de pago para efectos de la aceptación de costos, deducciones, pasivos e impuestos descontables," added to Law 1430 of 2010. 
Tax Act provide that any expense over $₹ 20,000$ in one day will not be deductible if the payment is not made through bank instruments.

Several countries have mandated use of point-of-sales devices. In Kazakhstan, individual businesses of certain types are obliged to accept payment cards and, accordingly, must install point-of-sale terminals. In Turkey, self-employed doctors, dentists, and veterinarians must use point-of-sale devices in their offices. Another measure is to mandate enterprises employing more than ten employees to pay their salaries, including bonuses, through banks. This rule also affects payroll taxes, requiring that they be paid on behalf of employees, and personal income taxes, which are deducted from salaries as they are paid through banking channels, creating a clear audit trail. Other countries with cash payment caps-including France, Turkey, Greece, Italy, Sweden, Norway, and the Netherlands-legally require merchants to issue receipts for each transaction and have allowed merchants to refuse payment in cash to compel the use of cards at the point of sale. If followed, these measures would facilitate fiscal control, but it is not clear whether they are followed.

A number of countries have introduced special reporting or withholding requirements for cash payments to businesses. In Mexico, financial-sector institutions must report cash deposits made to taxpayers' accounts when the accumulated monthly amount of cash deposits exceeds MXN\$15,000. In 2009, the Mexican Central Bank set a MXN\$20,000 ceiling for checks payable to the bearer in order to combat fraud. The 2014 tax reform package also allows Mexican tax officials to screen credit card data. Using cash or precious metals for certain transactions over amounts specified in the law is prohibited. An example of a general major cash payment reporting system is the Form 8300 system in the United States. Any person engaged in a trade or business who receives more than US\$10,000 in one transaction or several related transactions must file a cash payment report to the Internal Revenue Service. The system, developed jointly by the Internal Revenue Service and the Financial Crimes Enforcement Network, is used by the government to track tax evaders and individuals profiting from criminal activities.

Considering the difficulties of ensuring the correct reporting of cash income, tax administrations are simultaneously aiming at tracing the deposit and use of cash revenues. Cash income will eventually be deposited in a private bank account, spent, or transferred abroad. Matching data on the wealth and spending behavior of a shadow economy business operator with data in his income tax return can reveal major discrepancies and hidden sources of income. Developing 360-degree profiles of high net-worth individuals is useful for tracking this hidden income and wealth.

Increasing tax revenues by broadening the tax base and further reducing the shadow economy has been at the center of tax policy and administration in the Republic 
of Korea since the National Tax Service was established as an independent agency in 1966. The tax incentives promoting use of electronically traceable payments made through credit cards, debit cards, and electronic cash receipts that the Korean government introduced in 1999 were a pioneering way to broaden the tax base in business-to-consumer transactions. It is now believed that these measures contributed to broadening the tax base to a great extent by curbing cash transactions. This paper analyzes how Korea successfully curtailed the shadow economy using these methods.

The second section defines the term "shadow economy" as it is used throughout the paper and describes policy measures adopted in many developed countries particularly in the European Union. The third section outlines the history of tax-related policy measures in Korea and its attempts to cope with income underreporting, particularly through the TIETP. The fourth section provides statistical and empirical information regarding the performance of TIETP. In particular, its effects on the tax revenue and income redistribution are thoroughly discussed. The last section briefly discusses policy implications.

\section{THE SHADOW ECONOMY AND POLICY MEASURES ADOPTED TO COMBAT IT}

\section{What Is the Shadow Economy?}

Although the term "shadow economy" has been variously defined in relation to specific research objectives and data, one widely accepted definition is "concealed production and the underground economy," adopted by the System of National Accounts in 1993 and subsequently readopted in the Organisation for Economic Co-Operation and Development handbook, Measuring the Non-Observed Economy (2002), as follows:

Certain activities may be both productive in an economic sense and also quite legal (provided certain standards or regulations are complied with) but deliberately concealed from public authorities for the following kinds of reasons:

(a) To avoid the payment of income, value added or other taxes;

(b) To avoid the payment of social security contributions;

(c) To avoid having to meet certain legal standards such as minimum wages, maximum hours, safety or health standards, etc.;

(d) To avoid complying with certain administrative procedures, such as completing 
statistical questionnaires or other administrative forms.

(Commission of the European Communities et al. 1993, p.153)

This paper focuses on the shadow economy comprising productive legal activities concealed from tax authorities to avoid the payment of income, value-added, or other taxes, that is, category (a) of the definition. However, category (a) sometimes, or even usually, overlaps with (b), (c), or (d); therefore, any tax policy measures intended to curtail the kinds of payments that make up category (a) may have effects on the kinds of payments that make up the other subcategories of the shadow economy as a positive by-product. Unregistered microfirms, for example, operate completely outside the formal economy and attempt to avoid meeting minimum wage standards or paying social security contributions, as well as income tax, and value-added tax as a matter of course. Therefore, any tax measures aimed at bringing such unregistered firms into the formal economy and getting them to pay taxes will simultaneously reduce instances of the type of noncompliance described in subcategories (b), (c), or (d). Tax compliance measures aimed at registered firms that partly underreport their sales to avoid income- or value-added tax would also have a limited effect on the kinds of payments the comprise the other categories in the shadow economy.

\section{What Are the Key Characteristics of the Shadow Economy?}

Many countries, whether developed or developing, have shadow economies. The causes of shadow economies are manifold. According to Feld and Schneider's summary of thirty-two studies on the shadow economy and its causes, "increase of the tax and social security contribution burdens" was by far the most important single contributor to the growth of the shadow economy, followed by "tax morale," "quality of state institutions," and "specific labor market regulations" (2010). However, contrary to traditional thinking that the tax burden is a significant driver of the shadow economy, some scholars have presented opposing empirical research results showing that the tax burden has a negative correlation with the shadow economy (Friedman, Johnson, \& Kaufmann 2000; Stankevičius \& Vasiliauskaite 2014). Cumbersome labor-market restrictions, loss of access to the formal financial sector, and weak governance and institutions also determine the size of the shadow economy (Singh, Jain-Chandra, \& Mohommad 2012). Even if the tax burden is not a key driver of the shadow economy, noncompliance with tax laws remains one of its manifestations. Any measures to bring people into compliance with tax laws would curtail the shadow economy and at the same time contribute to addressing causes of the shadow 
economy other than taxation.

The shadow economy defined from the perspective of taxation comprises two types of activities: (i) activities of unregistered informal enterprises (including individuals) operating completely outside the formal economy (undeclared work), and (ii) activities of registered companies in the formal sector intentionally underreporting their sales (underreporting). Informal firms that do not register and that operate outside the formal economy evade paying taxes and do not comply with other mandatory legal requirements, such as paying employees the minimum wage or social security contributions. Registered formal firms can also underreport their income to evade payment of taxes, especially in cash-intensive businesses. In some cases, formal firms can also avoid compliance with legal requirements through undeclared work by unregistered workers. Meanwhile, people who want work but who are not competitive in the labor market, such as the elderly, women, ethnic minorities, illegal immigrants, and recipients of government transfers, are also voluntarily or involuntarily hired informally. Shadow economy firm owners tend to hire those people at very low wages, do not pay their share of social security contributions, and do not abide by other legal obligations in relation to hiring. Firms can evade income tax, VAT, and social security contributions completely or partially, while informal employees in those firms are not subject to income tax, their share of social security contributions, and reduction in (or termination of) government transfers. Individuals who buy goods and services from the firms operating in the shadow economy can benefit from lower prices that tax evasion makes possible. All participants in the shadow economy have shared interests and benefit from it, and so in most cases, they enter into secret collusive relationships that are difficult for public authorities to identify.

The collusive and secretive nature of these relationships leads parties to informal transactions to avoid using record-traceable transaction means, such as bank transfer, credit card, or check- or debit card payments. They prefer cash transactions that do not leave footprints traceable by tax authorities. Informal firms pay out or receive cash only for business purposes, and they also pay cash salaries to their informal employees. Formal companies seeking to evade taxes also prefer cash transactions and pay their informal employees in cash. Figure 2 illustrates the two types of shadow economy: undeclared work and underreporting. 
Figure 2. Two Types of Shadow Economy and Their Structures

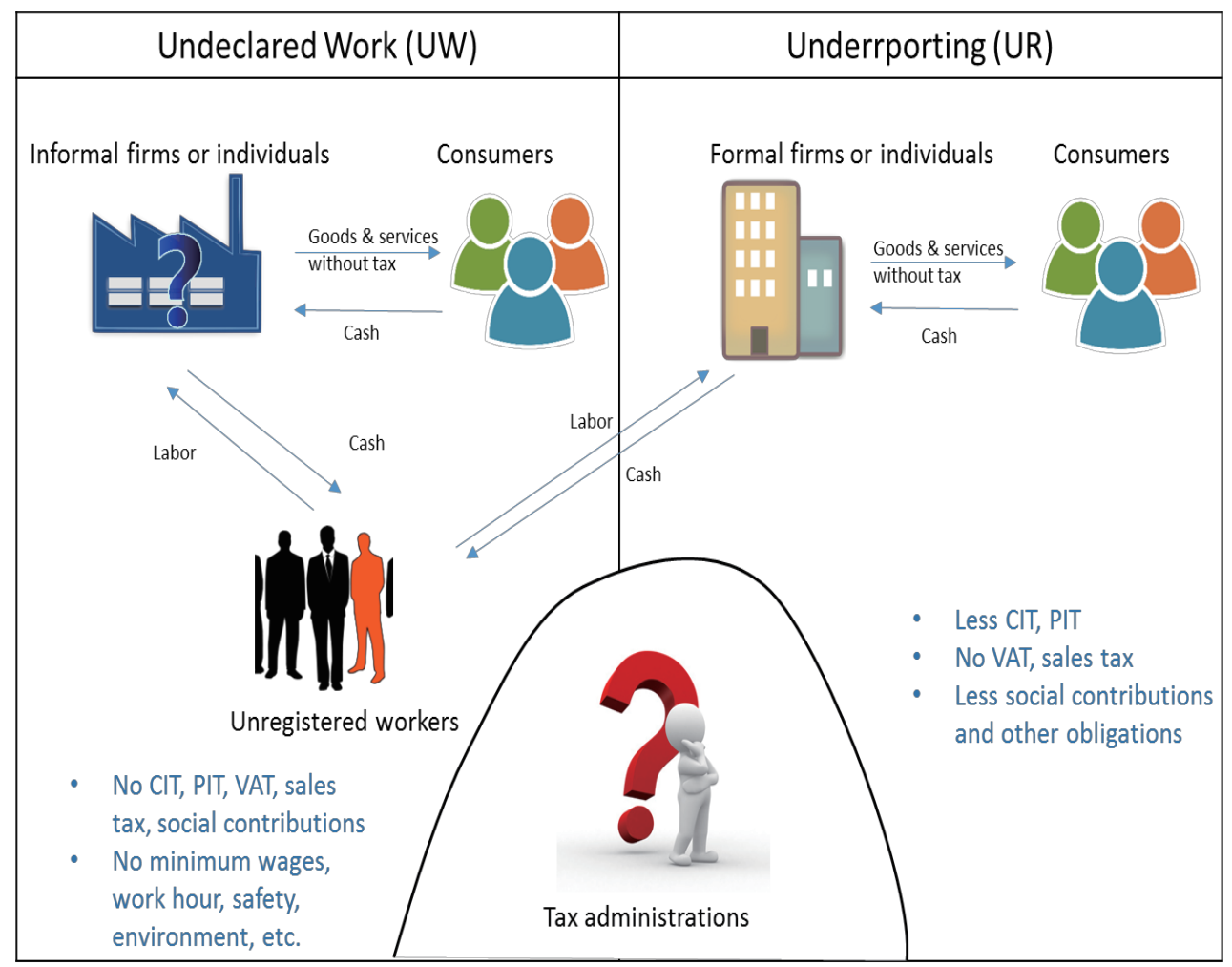

\section{What Policy Measures Can Reduce the Shadow Economy?}

Measures to reduce the shadow economy that do not tackle its core aspects or that focus on piecemeal reforms may be ineffective. For example, lowering the barriers to business registration, by, for example, simplifying the registration process, scrapping unnecessary registration documentation, and lowering legal requirements for registration, may facilitate formalization and yet fail to make significant headway toward curbing the shadow economy in the absence of other comprehensive measures to turn informality into formality. Although liberalization with respect to registration per se is a good policy for the business environment, it may not be enough to undermine the shadow economy, since informal firms have various reasons for remaining informal, including avoiding paying taxes, making onerous social security contributions, and meeting other labor condition standards, it would be difficult to convert informality to formality merely by deregulating registration. Mexico provides an example. Mexi- 
co reformed and simplified its local business registration process, which led to an uptick in the number of new business registrations, but the reforms do not seem to have induced unregistered businesses to register (Rruhn 2008). In the face of this, Perry et al. (2007) and Choi et al. (2013) suggest a wider, more integrated approach to inducing formality, one that would combine carrot and stick policies. Policy measures that directly address a key aspect of the shadow economy-collusive cash transactions - are necessary to induce informal firms to enter the formal economy. If using cash for payment is made difficult for participants in the shadow economy, the shadow economy will shrink. Recent support for this approach has been supplied by K. S. Rogoff (2016), who envisions a bold currency policy that phases out cash altogether to eliminate tax evasion and reduce crime. Also very worth keeping an eye on are the longer-term effects of India's abrupt revocation in 2016 of two of its highest-denomination notes (the ₹ 500- and 1,000- notes), seemingly undertaken to achieve goals similar to those advocated by Rogoff. This section explores various tax policies or administrative measures used by a number of countries to induce businesses to switch from informality to formality.

\section{Policy Measures Adopted to Deter Undeclared Work}

The EU countries regard undeclared work as more problematic than underreported goods or services (Jensen \& Wöhlbier 2012, p.27). Undeclared work accounts for roughly two-thirds of the shadow economy - the other one-third comes from underreporting - and half of the roughly 200 measures that have been adopted in European countries to combat the shadow economy focus on undeclared work (A. T. Kearney, VISA, \& Schneider 2013). Deterrent measures, such as identifying, criminalizing, and penalizing undeclared work, were prevalent in EU countries, but recently they have begun to adopt incentives designed to induce voluntary compliance instead (Williams 2009). According to a survey of policy measures adopted in the EU countries, almost all countries impose administrative or penal sanctions on either purchasers or suppliers of goods and services involved in undeclared work (Dekker et al. 2010). However, despite the fact that buyers benefit from tax evasion, fewer countries impose penalties on purchasers (Jensen \& Wöhlbier 2012, p.28).

In Italy, for example, under the Decreto Bersani, a law passed in 2006, a retailer that fails to issue a sales receipt three times in a five-year period can be forced to close, and construction sites can be shut down if employment irregularities are found. It is also illegal to use cash to pay more than $€ 100$ for professional services (A. T. Kearney, VISA, \& Schneider 2009). Buyers of undeclared work must keep receipts to present if asked to tax authorities to avoid sanctions. Norway requires purchasers 
to pay using electronic means or to keep invoices for a specified time to avoid criminal liability for purchases of undeclared services (Jensen \& Wöhlbier 2012, p.28). Penalizing both providers and buyers of undeclared work can be more effective in sabotaging the collusive relationship between them. However, the process of monitoring a large number of small and micro businesses to determine whether they are issuing receipts - and then ensuring that the general public keeps those receipts - is almost impossible, given the tax authorities' limited resources. Those measures have potential deterrent effects, but they may not be implementable in practice. Many scholars have therefore questioned the effectiveness of deterrent measures, in general, including detecting and punishing (Williams \& Schneider 2016, pp.147-148).

Another noticeable deterrent measure for reducing overall cash transactions that can lead to tax evasion and fraud has been rolled out by Belgium, Bulgaria, the Czech Republic, Denmark, France, Greece, Hungary, Italy, Portugal, and the Slovak Republic, which have introduced cash payment limits, mostly since the crisis of 2012, as shown in table 1.

Table 1. Cash Payment Restrictions in the European Union

\begin{tabular}{l|l|l}
\hline Belgium & $€ 3,000$ & January 1,2014 \\
\hline Bulgaria & JB 10,000 $=€ 5,112)$ & July 1,2011 \\
\hline Czech Republic & Kč350,000 $(=€ 12,763)$ & January 1, 2013 \\
\hline Denmark & kr10,000 (=€1,340) & \\
\hline France & $\begin{array}{l}€ 3,000 \text { (resident and nonresident sellers) } \\
€ 15,000 \text { (nonresident consumers) }\end{array}$ & July 1, 2012 \\
\hline Greece & $€ 1,500$ & January 1, 2002 \\
\hline Hungary & Ft1.5 million $(=€ 5,000)$ (legal persons) & January 1, 2013 \\
\hline Italy & $€ 999.99$ & December 6, 2012 \\
\hline Portugal & $€ 1,000$ & May 14, 2012 \\
\hline Slovak Republic & $€ 5,000$ & January 1, 2013 \\
\hline Spain & $€ 2,500$ (residents) & November 19, 2012 \\
\hline
\end{tabular}

Source: Beretta 2014. 
Such limits force people to make electronic payments, leaving a trail tax authorities can trace. However, legislation enabling tax authorities to access this information must be passed, which has not happened in all EU member countries (Jensen \& Wőhlbier 2012). In addition, the European Central Bank warns that although such limitations on cash payments comply with EU law, they should be carefully weighed so that a balance is achieved between the policy's objectives and its possible negative effects, namely, overly restricting individuals' freedom of economic activity (European Central Bank 2014a, 2014b). ${ }^{2}$ Another question regarding this approach is how cash limits can be enforced, given that cash transactions are typically collusive. If buyers and sellers agree to pay and receive cash without leaving a financial footprint, the relevant authorities' ability to detect those transactions and enforce cash limits remains questionable.

\section{Incentive Measures to Curtail Undeclared Work}

Measures to induce voluntary compliance by providing monetary or nonmonetary incentives have been introduced in several EU countries. One prominent incentive scheme addresses household services, which tend to remain undeclared work in the European Union. In recent years, tax deductions or direct subsidies for purchasers of household services have been introduced to support their expense for cleaning, cooking, laundry, home maintenance, and care for children, the elderly, and the disabled. The overall goals are to induce undeclared work to enter the formal economy and to create jobs in several EU countries, although the scope of eligible services, the form of support, the amount of tax deduction or subsidy, and the specific conditions that have to be met to take advantage of the incentives differ between countries. Public interventions in different countries to narrow the expense gap between formal and informal service provision range from direct subsidies to household service providers or users to public revenue expenditure through tax deductions, tax exemptions, or VAT-reduced rates. Table 2 provides a summary of representative EU countries' tax incentives, excerpted from the European Commission report, Developing Personal and Household Services (2013).

2. "In any case, limitations on cash payments should be proportionate to the objectives pursued and should not go beyond what is necessary to achieve such objectives $\cdots$ Any negative impact of the proposed limitations should be carefully weighed against the public benefits expected to be derived from them" (European Central Bank 2014a, 2014b). 
Table 2. Tax Incentives for Household Services

\begin{tabular}{|c|c|}
\hline Belgium & $\begin{array}{l}\text { ax reductions are linked to the use of vouchers used to purchase household } \\
\text { evices. Vouchers, available from Agences locales d'emploi and Titre services } \\
\text { e eligible for tax deduction, the former } 30 \% \text { and the latter } 30 \% \text { to } 40 \% \text {. The } \\
\text { iling for voucher tax deductions is } € 2,400 \text { (the total of both vouchers). }\end{array}$ \\
\hline Denn & $\begin{array}{l}\text { In } 1994 \text {, Denmark became the first country to introduce a subsidy of } 50 \% \text { of } \\
\text { cost to support household services, such as garden work, snow clearance, } \\
\text { shopping for daily goods, cooking, cleaning, laundry, and window cleaning. } \\
\text { The benefit was reduced in 2004, and benefits were limited to people aged } 65 \\
\text { or older. } \\
\text { In } 2011 \text {, a tax credit was allowed to all private persons; however, it was } \\
\text { abolished in } 2013 \text {. }\end{array}$ \\
\hline Finland & $\begin{array}{l}\text { A tax deduction was introduced in } 1997 \text { for household services carried out in } \\
\text { the taxpayer's or an elderly relative's home. Under this program, if the tax } \\
\text { deduction is larger than the amount of the central government income tax, the } \\
\text { taxpayer's local government taxes can also be reduced. } \\
\text { Since } 2009 \text {, eligible services include household work, caregiving, and day- } \\
\text { care services at home; repair work; services for a leisure house; and IT } \\
\text { services. } \\
\text { The tax deduction is } 40 \% \text { of expenses paid to a company, small entrepreneur, } \\
\text { or a nonprofit organization ( } 60 \% \text { until } 2011) \text { and } 15 \% \text { of wages paid for hiring } \\
\text { an employee. } \\
\text { The person employing an individual is except from the social contribution } \\
\text { requirement. }\end{array}$ \\
\hline Fra & $\begin{array}{l}\text { France allows } 50 \% \text { of expenses for cleaning, ironing, IT assistance, and } \\
\text { private lessons as income tax deductions. } \\
\text { Tax deductions are given to households that either directly employ an } \\
\text { individual service supplier at home or that hire a service company. } \\
\text { The tax deduction ceiling is } € 12,000 \text { per year, but it can be increased } \\
\text { depending on the number of children, residents aged } 64 \text { or older, and } \\
\text { disabled residents. } \\
\text { Beginning in } 2007 \text {, if the eligible tax deduction surpasses the income tax, the } \\
\text { difference between them is reimbursed to help low- income households. }\end{array}$ \\
\hline Gern & $\begin{array}{l}\text { ax credit is allowed for up to } 20 \% \text { of the costs for household-related } \\
\text { ices, such as gardening, cleaning, laundry services, and childcare. } \\
\text { ddition, } 20 \% \text { of the wage costs for craft services, such as repairs and } \\
\text { vations, can be offset with income tax. }\end{array}$ \\
\hline Italy & $\begin{array}{l}\text { ouchers, but the scope of covered } \\
\text { ance of buildings, seasonal and } \\
\text { g events, and so on. }\end{array}$ \\
\hline Lux & $\begin{array}{l}\text { Tax reduction for the expense of housework services and care services for } \\
\text { dependent persons or children is allowed, but the maximum tax rebate is } \\
€ 3,600 \text { per year and } € 300 \text { per month. }\end{array}$ \\
\hline Swe & $\begin{array}{l}\text { Sweden's tax deduction for household services has two components: RUT } \\
\text { (cleaning, maintenance, servicing) and ROT (home renovation services). } \\
\text { Tax credits are allowed up to } 50 \% \text { of labor costs (including VAT) for } \\
\text { household services. The sum of the tax credits for RUT and ROT must not } \\
\text { exceed around } € 5,500 \text { per person per year. }\end{array}$ \\
\hline
\end{tabular}

Source: Authors' summary from European Commission (2013). 
Assessments regarding monetary support for household services are mixed. In 1998, the European Commission issued a positive evaluation of such policies, stating, "Tax-deductions and subsidies for re-furbishing and improvements of houses have been particularly successful in encouraging more people to use the opportunity to repair their houses legally, and had the effect of moving work which might have been done informally to the formal registered sector" (European Commission 1998). A paper published by European Commission fifteen years later (Jensen \& Wöhlbier 2012), however, notes that "although such tax credits and subsidies may have a positive impact on employment in the formal economy, they tend to be expensive in terms of foregone revenue, and the experienced results in terms of reduction of the shadow economy have not been convincing, in particular when compared to the cost of the measure. Moreover, these measures tend to introduce a 'trap' which might lock in this kind of household jobs." The most recent European Commission report acknowledges that these policies "proved to be quite costly," but it also offers analysis not only of gross public expense but also direct and indirect earn-back effects; for example, the data show a $45 \%$ reduction in net cost for public expense in Belgium and positive returns in Finland and France (European Commission 2013).

\section{Normative Policy Measures}

A softer approach to curbing the shadow economy that cultivates tax morale, enhances tax-system fairness, and encourages social norms for tax compliance is now being considered in EU states as a complement to traditional economic incentives and disincentives. This approach is widely discussed in the literature, and analysts generally consider it to be effective. However, the EU countries still depend heavily on traditional stick and carrot policies, and very few have adopted normative compliance measures, such as appeals to citizens to declare their activities, campaigns to encourage a culture of commitment to declaration, and efforts to change perceptions of the tax system's fairness (Williams \& Schneider 2016, pp.153-154).

\section{Policy Measures against Underreporting}

A number of OECD countries have attempted to tackle not only undeclared work but also underreporting in business-to-consumer retail sectors prone to falling into the shadow economy due to their heavy volume of cash transactions. ${ }^{3}$ All around the

3. The Canadian Restaurant and Food Services Association estimated suppressed sales of CAN\$2.4 billion for 2009 in the restaurant sector; Sweden recovered $€ 150$ million in 2,000 
world, electronic cash registers and electronic point-of-sale systems are manipulated via electronic sales suppression software known as phantomware and zappers to enable underreporting of sales(OECD 2013). To counter this kind of fraud, the Irish government, as of July 2008, made it mandatory that electronic cash registers record and retain sales entries in electronic format with uniquely identifiable sequential numbers, dates, and times, and it issued guidelines on requirements for proper record keeping (e.g., securing the integrity of data) for cash registers (Iris Revenue 2015). Many countries, including Argentina, Brazil, Bulgaria, Greece, Hungary, Latvia, Lithuania, Malta, Poland, Russia, Turkey, Venezuela, and Canada Quebec, have made the use of certified electronic cash registers or point-of-sale systems in targeted business sectors (e.g., restaurants) mandatory. Adding monitoring devices to the point-of-sale system, securing data with digital signatures, or transferring transaction data to tax authorities (OECD 2013) are methods that can prevent cash receipt skimming. This approach may not ultimately eradicate underreporting fraud in cases in which business sellers and customers agree to off-the-record cash transactions or when business sellers simply do not register cash transactions without receipts. Other problems with the certified cash register approach are the potential for too much interference by governments in private businesses and the high cost of the registers, which will restrict mandatory adoption to certain business sectors (Ainsworth \& Hengartner 2009).

Another approach to countering underreporting fraud is to provide incentives for customers to request receipts from businesses. Taiwan, China, introduced the "receipt lottery" in 1951 to encourage people to secure receipts when purchasing goods or services from businesses, which in turn prompted businesses to file their sales correctly according to their receipts issued. Mainland China likewise introduced mandatory lottery receipts in all tax bureaus in 2009 after experimenting with the concept in more than 80 big-city-level tax bureaus, including Beijing, Shanghai, and Tianjin (Wan 2010). According to Wan's analysis, lottery receipts increased sales tax and total tax revenues significantly in the experiment areas (2010). Puerto Rico also introduced a sales-and-use tax receipt lottery in 2011 but then eliminated it in 2015.4 Sao Paulo, Brazil, in contrast, introduced VAT rebates for receipts. End consumers collecting receipts are able to receive tax rebates of $20 \%$ of the VAT paid by the final sales establishment. In addition, lottery tickets are given for every

audits over four years; and Norway found a single case involving underreporting of $€ 7$ million (OECD 2013).

4. Anna Karuvilla, "Puerto Rico Eliminates the Sales Tax Lottery," Reuters, November 3, 2015, https://tax.thomsonreuters.com/blog/onesource/vat-gst-management/puerto-rico-eliminates-sales-tax-lottery. 
US\$50 purchase. This Nota Fiscal Paulista program has increased firms' reported revenues by at least 22\% (Naritomi 2015).

Table 3 offers a summary of policy measures for reducing informal firms' or individuals' undeclared work and formal firms' underreporting. Policy measures can be categorized according to targets, which include sellers and buyers. A further classification is by policy approaches: deterrent, incentivizing, and normative. The policy measures mapped in this matrix reduce undeclared work, underreporting, or both. Normative approaches can be divided into "seller" and "buyer" categories but they are presented here without distinction.

Table 3. Policy Measure Matrix

\begin{tabular}{l|l|l}
\hline & \multicolumn{1}{|c}{ Seller } & \multicolumn{1}{c}{ Buyer } \\
\hline $\begin{array}{l}\text { Deterrent } \\
\text { Measures }\end{array}$ & $\begin{array}{l}\text { criminalization (undeclared work) } \\
\text { monitoring and auditing (undeclared } \\
\text { work and underreporting) } \\
\text { penalties for not invoicing (undeclared } \\
\text { work and underreporting) } \\
\text { mandatory use of electronic cash } \\
\text { register or point of sale } \\
\text { (underreporting) }\end{array}$ & $\begin{array}{l}\text { (ciminalization (undeclared work) } \\
\text { penalties for not getting receipts } \\
\text { (undeclared work and underreporting) } \\
\text { cash payment limits (undeclared work } \\
\text { and underreporting) }\end{array}$ \\
\hline $\begin{array}{l}\text { Incentivizing } \\
\text { Measures }\end{array}$ & $\begin{array}{l}\text { leregulating registration process, } \\
\text { lowering expenses for formalization } \\
\text { (low taxes, low burdens for } \\
\text { employment, and other deregulations) } \\
\text { (undeclared work) } \\
\text { tax incentives for e-payments } \\
\text { (undeclared work and underreporting) }\end{array}$ & $\begin{array}{l}\text { tax incentives or direct subsidy for } \\
\text { home services (undeclared work) } \\
\text { tax incentives to make electronically } \\
\text { traceable payments (underreporting) } \\
\text { cash rebates for receipts } \\
\text { (underreporting) } \\
\text { receipt lotteries (underreporting) }\end{array}$ \\
\hline $\begin{array}{l}\text { Normative } \\
\text { Measures }\end{array}$ & $\begin{array}{l}\text { tax education and public awareness (undeclared work and underreporting) } \\
\text { enhancing tax morale and cultivating a compliance culture (undeclared work } \\
\text { and underreporting) } \\
\text { building trust regarding tax policy and administration (undeclared work and } \\
\text { underreporting) }\end{array}$ \\
\hline
\end{tabular}




\section{KOREA'S ATTEMPT TO REDUCE UNDERREPORTING IN RETAIL BUSINESSES}

\section{Efforts to Broaden the Tax Base}

The history of domestic resource mobilization in the Republic of Korea is characterized by the tax authority's efforts to increase revenue and enhance tax equity by broadening the tax base, taxing in such a way as to finance Korea's economic and social development needs. The National Tax Service was established as a separate organization from the Ministry of Finance in 1966 to mobilize more effectively the tax revenue needed to finance the country's government-led national economic development plan consisting of seven five-year plans that was introduced in 1962 and concluded in 1996. In 1975, a global income tax on aggregate income, including labor income, business income, real estate rent income, and other miscellaneous incomes was introduced to enhance tax equity. Value-added tax was introduced in 1977 to enable evidence-based taxation and to prevent tax evasion by cross-checking VAT invoices. At that time, the government instituted a cross-check process by requiring taxpayers to submit all invoices when they filed VAT returns. Cross-checks are now done electronically through mandatory e-invoicing. In 1993, mandatory use of real names and a prohibition on the use of pseudonyms for financial transactions were introduced to enhance the transparency of financial transactions and to prevent illicit financial flows. The mandatory use of real names set the stage for the global financial income tax levied on aggregate financial incomes, including interest and dividends, introduced in 1996 to enhance tax equity for financial income.

Another drastic change in tax administration in 1996 was the shift from taxation based on government assessment to a voluntary system. Before the voluntary income tax return system was instituted, the National Tax Service either assessed taxpayer's income tax liabilities based on their bookkeeping and other records or it accepted taxpayer income tax returns that complied with preset standards or that reported income above the preset standard income-to-sales ratio the National Tax Service established for specific business sectors, geographical areas, and business scales. After abandoning the government assessment system, however, the National Tax Service faced a big challenge: how could it verify taxpayers' voluntary income tax returns? The most problematic areas were the business-to-consumer retail sectors with heavy cash transactions; examples include professional service sectors, hotels, restaurants, bars, salons, pharmacies, and other retail stores. While business-to-business transactions were traceable through VAT invoice audit trails, business-to-consumer transactions, especially cash sales, could not be traced by tax authorities. End consumers had no 
incentive to obtain receipts or report purchases to tax authorities, unlike businesses, which are able to claim input VAT credit against their output VAT. Accordingly, tax policy and tax administration authorities began exploring more fundamental approaches for creating audit trails for business-to-consumer cash transactions.

\section{Introduction and Failure of Mandatory Cash Register Use}

Since 1977 when the VAT was introduced, Korea's tax authorities have made efforts to effectively capture the sales of cash-intensive industries using the invoice credit VAT system. That same year, the Ministry of Finance rolled out comprehensive legal provisions to prevent underreporting in retail sectors. ${ }^{5}$ VAT law made the use of cash registers mandatory for designated cash-intensive businesses, and penalties were levied against business that failed to install cash registers, neglected to issue receipts, and altered cash sales. ${ }^{6}$ In addition to the deterrent measures, tax incentives were instituted for both retailers and consumers. Retailers using cash register received a tax credit against VAT payable ( $0.5 \%$ of cash-register-recorded sales). In addition, customers who collected and submitted cash-register-issued receipts to the government were given cash compensation: $1 \%$ of the purchase value. In line with the government support for cash register use and receipt exchange in the retail sectors, Korea's Chamber of Commerce and Industry and many consumer NGOs allied with the National Tax Service to run a nationwide campaign to educate and encourage retailers to issue receipts and consumers to ask for them. ${ }^{7}$ In fact, the receipt campaign had been introduced in 1966, when the National Tax Service was established, but it was not particularly successful. It was relaunched when the VAT was introduced. Believing that receipt-exchange practices were vital to the success of the newly adopted VAT and their efforts to tax on the basis of information and evidence, tax authorities strongly advocated that cash registers be installed in cash-intensive retail sectors and that retail businesses issue receipts to consumers.

These policy measures failed, however, despite continuous efforts by tax authorities into the early 1990s. Retailers did install cash registers, but they were reluctant to

5. Article 32, VAT Law; articles 82 and 83 of VAT presidential decree, effective as of January $1,1977$.

6. The penalty was very strong: a 15-day business suspension for two detected instances of nonprovision of receipts or manipulation of cash sales within a 90-day period, and business closure for three detected instances. The penalty for failure to install cash registers was \#500,000.

7. "Korea Chamber of Commerce Campaign for Issuing and Receiving Receipts," Kyunghyang Shinmun, January 18, 1977. 
issue receipts through them, and if consumers did not request receipts, they did not issue them and so were able to continuing dropping off cash sales to evade the tax burden. In response to taxpayers' presumed underreporting and tax evasion, tax authorities even rejected retailers' VAT and income tax returns and assessed much higher taxes above the sales recorded in the cash registers. ${ }^{8}, 9$ This move by tax authorities led to friction with taxpayers, criticism from the public, and distrust toward government policies and authorities. In addition, despite the lure of compensation for obtaining cash register receipts, consumers did not actively do so because the application process for receipt compensation was cumbersome and inconvenient and the economic benefit was relatively small. ${ }^{10}$ Even worse, finding the system ineffective, the Korean government abruptly abolished receipt compensation program after only three years, thus eliminating the only incentive that might have helped consumers come to appreciate the long term benefit of obtaining receipts. ${ }^{11}$

Distrust between taxpayers and tax authorities, the low tax morale of taxpayers, the repeal of the receipt compensation program, and functional defects in cash registers eroded the effectiveness of the cash register policy. Following the presidential and parliamentary elections in 1978, tax authorities sought to reduce friction with taxpayers, and in the early 1980s they almost totally suspended investigation into and penalties for failure to issue receipts. ${ }^{12}$ In 1988 , the mandatory use of cash registers was de facto abolished, on the grounds that it had been enforced for the convenience of the tax administration and that it in fact discouraged the issuing and receiving of receipts, despite its original objectives, after a number of swings between strong enforcement and soft encouragement. ${ }^{13}$ In 1993, the article in the VAT law making

8. A news article in the Kyunghyang Shinmum (September 27, 1979) reported that cash registers became useless due to businesses' neglect in issuing receipts and consumers' lack of awareness of receipts. It also reported that fewer than 1 in 10 customers in restaurants obtained receipts, and no one obtained receipts in grocery stores. According to a taxpayer who equipped his business with a very expensive cash register at the urging of tax officials, tax inspectors did not assess taxes based on the cash register records but levied a $20 \%$ additional tax.

9. "Equipped with an Expensive Cash Register but Distrusted," Dong-a Ilbo, February 20, 1979.

10. "Urgent to Make Receipt Exchange a Practice after One Year of Campaign," Mail Economy, February 7, 1978.

11. "Receipt Compensation To Be Abolished Next Year after Three-Year Trial Proves Ineffective," Dong-a Ilbo, September 24, 1979.

12. "Enforcement of Cash Registers Is a Lost Cause," Mail Economy, March 19, 1980; "Retarding VAT," Dong-a Ilbo, April 14, 1981

13. "Retailers, Allowed to Use Cash Registers Voluntarily," Mail Economy, August 2, 1988. 
cash register use mandatory was officially struck, and instead a statute was introduced supporting voluntary use of cash registers. ${ }^{14}$ Tax credits to business sellers for issuing cash register receipts $(0.5 \%$ of sales $)$ were maintained to encourage voluntary cash register use. In 1996, however, even the tax credit for cash register receipts was repealed, as cash registers had proven ineffective in reducing underreporting of cash sales. ${ }^{15}$

\section{The Introduction of TIETP}

After the mandatory use of cash registers proved to be a failure, tax authorities in Korea decided to develop other policy and administrative options to prevent underreporting. In the late 1980 s, they began to focus on electronic payments, such as credit card payments, that would enable tax authorities to follow the retail sectors' audit trails. In 1984, the Ministry of Finance introduced regulations requiring large-scale businesses (above $\$ 10$ billion in sales) to submit detailed lists of tax-deductible business entertainment expenses to the National Tax Service that were not paid using credit cards. ${ }^{16}$ In 1986, the National Tax Service requested that credit card companies submit taxpayers' credit card transaction data, which it was allowed to do under the Credit Card Business Law for purposes of tax inquiries or investigations. The National Tax Service thereafter began to use credit card transaction information to verify retail businesses' tax returns (Jang 1997, p.178). The effects of this approach were limited, however, since cash was still used for a significant number of transactions.

From the mid-1990s on, when personal income taxation in Korea went from being a matter of government assessments to a matter of voluntary reporting, cash transactions without receipts and underreporting became much more serious challenges to the Korean tax authorities. The National Tax Service would not assess taxpayers' voluntary tax returns if it did not have clear counterevidence to taxpayers' assertions, and it could no longer enforce income taxation on the basis of its own income-tosales ratio criteria.

In 1994, against this backdrop, the Ministry of Finance introduced a tax incentive for credit card use $-0.5 \%$ of credit card sales would be credited to VAT payable for retail sellers dealing mainly in goods or services to consumers - and it abolished a

14. Article 32, VAT Law, effective as of January 1, 1994.

15. Paragraph 2, article 32, VAT Law, effective as of January 1, 1996.

16. Article 44-3, Corporate Income Tax Presidential Decree, effective as of October 5, 1985, and Article 106-2, Personal Income Tax Presidential Decree, effective as of October 5, 1985. 
similar tax credit for retailers who issued cash register receipts. ${ }^{17}$ Subsequently, in 1996, the ministry increased the tax credit rate from $0.5 \%$ to $1 \%$ (the ceiling of 3 million was put in place beginning in 1999). ${ }^{18}$ As of January 1, 2000, the tax credit rate was increased to $2 \%$, with a ceiling of $\$ 5$ million. ${ }^{19}$ Policy slowly turned in the direction of favoring credit card payments over cash register receipts.

Allowing tax incentives to end consumers paying with credit cards was a contentious issue, however. In 1995, the Ministry of Finance started to review tax deductions for wage earners who used credit cards to increase electronically traceable payments. ${ }^{20}$ In 1999, TIETP was finally introduced. ${ }^{21}$ TIETP is a completely different form of tax incentive for individual consumers. It gives tax incentives to the general public for almost all credit card payments, but even though this would suggest its fiscal impact would be substantial, its effectiveness in preventing underreporting has remained unclear. Korea already had experience in giving consumers incentives under the program that provided compensation for collecting cash register receipts, but this had proved to be a failure due to taxpayers' disregard of cash register receipts, the inconvenient compensation application process, delays in compensation due to poor management, and the government's slow budget allocation or budget shortfalls. ${ }^{22}$ Despite these problems in the implementation process, consumer compensation nonetheless slowly took root, as evidenced by the compensation amounts disbursed: $\$ 1.4$ billion in 1977 , 2.76 billion in 1978 , and $\$ 2.52$ billon in the first half of 1979. ${ }^{23}$ This progress notwithstanding, the budget proposal for consumer compensation submitted by the National Tax Service was abruptly rejected by the Economic Planning Board after only three years of implementation on the grounds that it was costly and ineffective in reducing underreporting. ${ }^{24}$ The government poli-

17. Paragraph 1, Article 32-2, VAT Law, effective as of January 1, 1994.

18. Paragraph 1, article 32-2, VAT Law, effective as of January 1, 1996; paragraph 1, article 32-2, VAT Law, effective as of January 1, 1999.

19. Paragraph 1, article 32-2, VAT Law, effective as of January 1, 2000.

20. "Tax Deduction for Credit Card Use," Mail Economy, May 18, 1995; "Tax Deduction for Credit Card Use to Wage Earners," Mail Economy, July 26, 1995.

21. Paragraph 126-2, Preferential Tax Control Law, effective as of August 31, 1999.

22. "Urgent to Make Receipt Exchange a Practice After One Year of Campaign," Mail Economy, February 7, 1978; "Delayed Compensation for Receipts Is Not a Trivial Problem," Mail Economy, July 10, 1978; "Problems with Receipt Compensation," Kyunghyang Shinmun, March 26, 1979; "Receipt Compensation," Kyunghyang Shinmun, December 27, 1979.

23. "Receipt Compensation To Be Abolished Next Year after Three-Year Trial Proves Ineffective," Dong-a Ilbo, September 25, 1979.

24. Ibid. 
cy encouraging receipt exchange in retail sectors to prevent underreporting and to enable evidence-based taxation was significantly undermined by this retrograde measure. ${ }^{25}$ After the revocation of the receipt compensation program, there were intermittent requests for its reinstatement. ${ }^{26}$ But that did not happen until the introduction of TIETP in 1999.

Starting in 1998, the Ministry of Finance and Economy undertook a series of measures to encourage credit card payments in the belief that these would provide reliable tax information regarding sales in retail businesses and would contribute to enhancing business transaction transparency. ${ }^{27}$ First, the ministry revised the income tax and VAT laws to enable the National Tax Service to designate specific retail businesses primarily selling goods and services to individual consumers as credit-card-membership target businesses and to strongly recommend to those businesses that they join this program. ${ }^{28}$ In practice, such recommendations made by the National Tax Service, which had power to initiate tax audits, were seen as de facto mandatory. ${ }^{29}$ Simultaneously, regulations pertaining to tax-deductible business entertainment expenses were strengthened, so that any business entertainment expense exceeding \$5,000 (approximately US\$50) had to be paid for with a credit card or VAT invoice to be eligible for tax deduction. ${ }^{30}$ Such strict rules were believed to enhance transparency of business expenses and to uncover hidden sales by retail businesses.

The Ministry of Finance and Economy took care to prevent TIETP from introducing double tax deductions; for example, medical expenses or insurance premiums

25. "After the Abolishment of Receipts Compensation, Receipt Exchange Petering Out," Mail Economy, August 26, 1980.

26. "Introduction of Receipts Compensation Desirable, Effective in Reducing Underground Economy," Mail Economy, April 6, 1983; "NTS Reviews Revival of Receipt Compensation," Mail Economy, May 18, 1985; "The Federation of Korean Industries Suggests Introducing Tax Deduction for Receipts or Reviving Receipt Compensation," Dong-a Ilbo, August 5, 1985; "NTS, Insufficient Measures for Receipts Exchange," Mail Economy, November 4, 1985.

27. "Mandatory Credit Card Membership for Hospitals, Pharmacies, and Hotel Businesses," HanKyoreh, June 5, 1998.

28. Article 162-2, Income Tax Law, effective as of January 1, 1999; article 32-2, VAT Law, effective as of January 1, 1999.

29. "Mandatory Credit Card Membership for Hospitals, Pharmacies, and Hotel Businesses," HanKyoreh, June 5, 1998; "Hospitals, Private Educational Institutions, Restaurants, Hotel Businesses Will Be Subject to Tax Investigation, If They Show a Decline in Credit Card Payments," Kyunghyang Shinmun, December 14, 1998.

30. Article 35, Income Tax Law, effective as of January 1, 1999; article 25, Corporate Income Tax Law, effective as of January 1, 1999. 
deductible from wage income under the income tax law could also be tax deductible under TIETP if they were paid for by credit card, leading to a double deduction. In July 1999, the ministry announced that it had made adjustments to TIETP that would eliminate double deductions and minimize the fiscal impact of the new experiment.

\section{RATIONALE FOR TIETP}

\section{Policy Shift to Measures Aimed at End Consumers}

Policy experiments adopted by Korean tax authorities to date to reduce underreporting in the retail sectors are presented in table 4, following the framework presented in table 3. Deterrent measures such as mandatory cash register installation and penalties for not issuing receipts proved to be failures and were abandoned. Policies encouraging compliance by sellers and buyers, including tax incentives for cash register receipts and cash compensation to consumers for submitting receipts, were transformed into tax incentives for credit card sales and TIETP.

Table 4. Korea's Policy Experiments to Reduce Underreporting in Retail Sectors

\begin{tabular}{|c|c|c|}
\hline & Seller & Buyer \\
\hline $\begin{array}{l}\text { Deterrent } \\
\text { Measures }\end{array}$ & $\begin{array}{l}<\text { S-D cell> } \\
\text { * monitoring and auditing } \\
\text { (underreporting) } \\
\text { * penalties for failing to issue receipts } \\
\text { (underreporting) } \\
\text { * mandatory use of cash registers } \\
\text { (underreporting) }\end{array}$ & $\begin{array}{l}<\mathrm{B}-\mathrm{D} \text { cell }> \\
\mathrm{NA}\end{array}$ \\
\hline \multirow{3}{*}{$\begin{array}{l}\text { Incentivizing } \\
\text { Measures }\end{array}$} & $\begin{array}{l}<\text { S-I cell> } \\
\text { * tax incentives for issuing cash } \\
\text { register receipts (underreporting) }\end{array}$ & $\begin{array}{l}<B-I \text { cell }> \\
{ }^{*} \text { cash compensation for securing } \\
\text { receipts (underreporting) }\end{array}$ \\
\hline & & \\
\hline & $\begin{array}{l}\text { * tax credit for credit card sales } \\
\text { (underreporting) }\end{array}$ & * TIETP (underreporting) \\
\hline \multirow{2}{*}{$\begin{array}{l}\text { Normative } \\
\text { Measures }\end{array}$} & $<\mathrm{S}-\mathrm{N}$ cell $>$ & $<\mathrm{B}-\mathrm{N}$ cell $>$ \\
\hline & $\begin{array}{l}\text { * campaign and education on receipt } \\
\text { exchange (underreporting) }\end{array}$ & $\begin{array}{l}\text { * campaign and education on receipt } \\
\text { exchange (underreporting) }\end{array}$ \\
\hline
\end{tabular}


Korea's experience prior to introducing TIETP was that deterrent measures were ineffective. Normative approaches were also not effective in Korea, a strongly government-led country in which public education and awareness campaigns, intrusive government guides, and recommendations are rampant. In addition, push policies targeting business sellers, including tax incentives for cash register receipts, were ineffective, because the benefits of this incentive did not compare to the illegal gains sellers could make from underreporting, especially in a society with low tax morale. Therefore, the question became whether a pull policy encouraging end consumers to provide third-party information would be effective in reducing underreporting. Under the invoice credit VAT system, business buyers report business sellers' sales by claiming their input VAT credit in business-to-business transactions. In business-to-consumer transactions, however, end consumers do not provide tax authorities with any information on business sellers' sales. Therefore, pull policies encouraging end consumers to play an active role in providing such information could be a very powerful tool for unveiling hidden transactions in cash businesses. If end consumers, encouraged by tax incentives, used electronically traceable payment means for purchases, tax authorities could access secure and reliable sales data on cash-intensive businesses. In the period after Korea revoked what hindsight shows to have been a poorly managed receipt compensation policy, he economic and social landscape of the country changed dramatically. In this altered landscape, TIETP was considered to be a different pull strategy for tackling cash transaction practices and breaking the collusive relationships among participants in the shadow economy.

Figure 3. Effectiveness of Korean Policies Aimed at Curbing the Shadow Economy

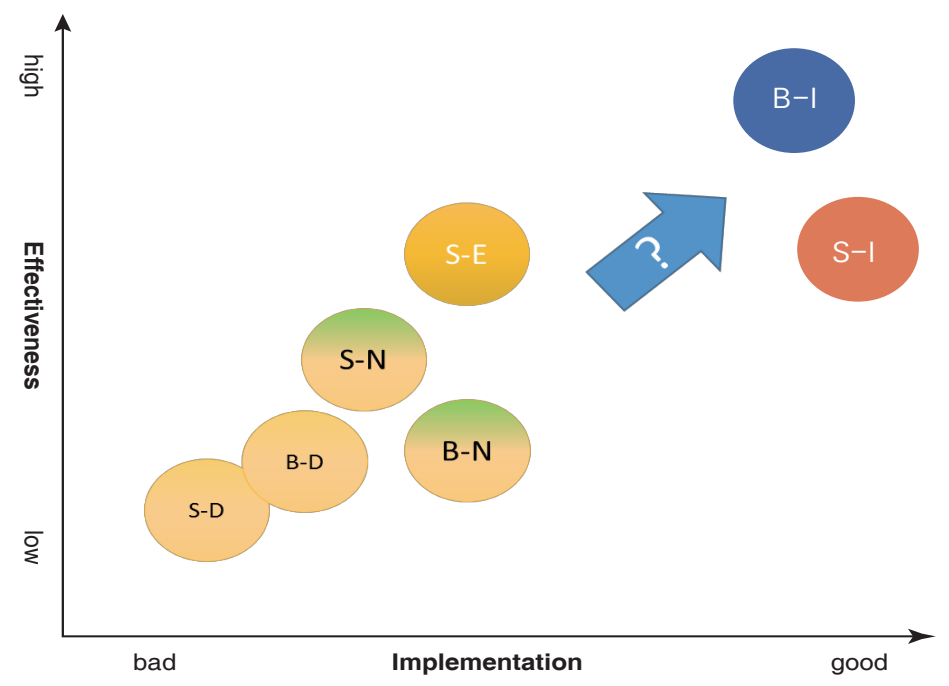

The Korean Journal of Policy Studies 
With the expectation that end consumers would switch to using credit cards if given tax incentives for doing so, Korea moved from seller-deterrent policies (S-D) and seller- and buyer-normative policies (S-N and B-N) that had failed in 1970s and 1980s to buyer-incentivizing and seller-incentivizing policies (B-I and S-I) at the end of 1990s. The following figure conceptually describes Korea's policy shifts and its aim to curb the shadow economy in retail sectors.

\section{TIETP Theoretical Framework}

The effect of TIETP is represented by the payoff matrix in table 5, illustrating the games business sellers and end consumers play in the market. First, if it were not for TIETP, end consumers would not have any incentive to use credit cards when purchasing goods and services in retail markets. The end consumer's payoff is zero, whether using credit cards or cash, in the absence of the tax benefit provided by TIETP. However, that is not the case for a business seller. If a customer does not use a credit card and the seller does not report the sale, then seller's payoff will be, for example, 10 (gain from tax evasion). However, if a customer uses a credit card, the seller is expected to report the sale, and so the seller's payoff will be zero (no gain) in that case, or, if the seller doesn't report the sale, then the payoff will be, for example, -20 (loss from the detection and punishment). Therefore, the equilibrium, in most cases, will be the worst case, the shaded area of the left matrix of table 5 ("does not use credit card-does not report"). That is because a seller has a strong incentive not to report sales to maximize payoffs when customers do not use credit cards. Sometimes, in expensive deals, a seller may collude with the customer in order to share the tax benefit; such payoffs are displayed in parenthesis.

Introducing TIETP to give tax benefits to end consumers, however, can alter the equilibrium. TIETP gives end consumers incentives to use credit cards, making the payoffs to end consumers 2, for instance, as shown in the right payoff matrix in table 5. The payoffs for business sellers are the same as without TIETP. In that case, the possibility with the highest payoff will be the case where end consumers request to use a credit card and business sellers report the sales accordingly ("uses credit card-reports," the shaded area of the right matrix). Nonetheless, again, sellers and buyers may collude to share benefits. For example, sellers can offer customers lower prices when they evade taxes and can request that their customers not use credit cards, especially for expensive transactions, the payoffs of which are displayed in parentheses in table 5. TIETP clearly cannot eliminate all underreporting. However, we can expect that, in most ordinary retail transactions, such as take place in restaurants, bars, pharmacies, and other small retail stores, the equilibrium will be "uses credit card-reports." 
Table 5. Payoff Matrix with and without TIETP

$<$ Without TIETP $>$

$<$ With TIETP $>$

End-consumer

End-consumer
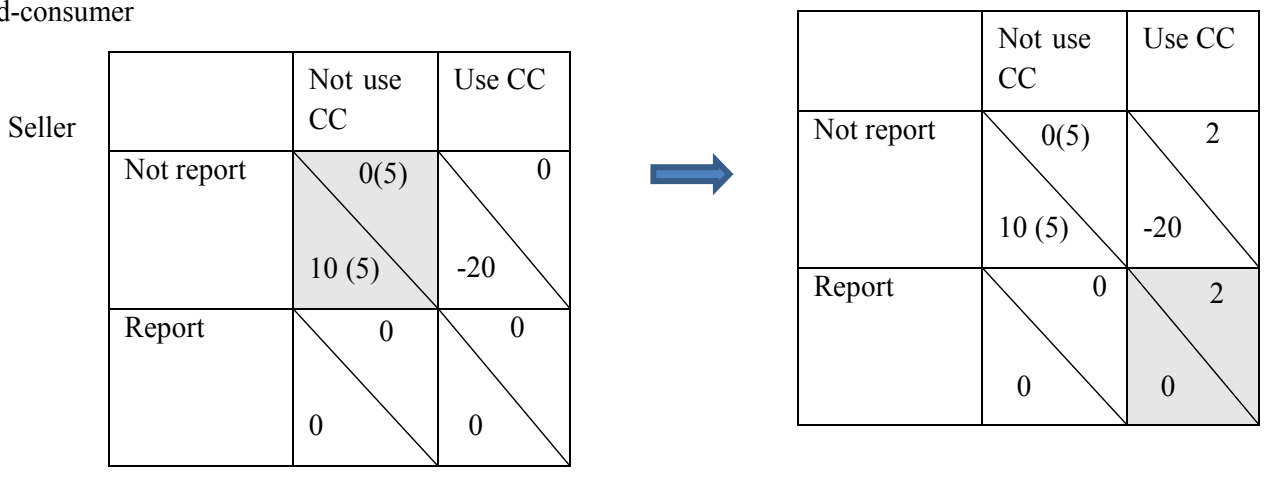

If the equilibrium changes from "does not use credit card-does not report" to "uses credit card-reports" with TIETP, then even if sellers and end consumers collude to share the benefits of tax evasion on expensive transactions, TIETP might contribute to curtailing the shadow economy. According to Jang's survey (1997), conducted before TIETP's introduction, while only $8.9 \%$ of survey respondents obtained receipts in retail stores, approximately $90 \%$ answered that they would pay with a credit card if the government introduced tax deductions for credit card payments. ${ }^{31}$ Another survey's results showed that $75.8 \%$ of respondents would use credit cards more frequently if tax incentives for their use were introduced. ${ }^{32}$

\section{TIETP Incentive Structures}

The Ministry of Finance and Economy designed TIETP in such a way as to limit the fiscal impact of the policy. TIETP offers tax deductions only on taxable labor income. It does not allow tax deductions on business income, real-estate rent income, or forest income, since expenses related to those incomes were already tax deductible under income tax law. The credit card tax deduction is limited at both ends by a mini-

31. 56\% used credit cards without exception; $5 \%$ only shopped at credit card member stores; $26 \%$ used credit cards even for small amounts; $10 \%$ said they did not have much interest in using credit cards; $2 \%$ said they had no interest; and $1 \%$ did not respond.

32. "Credit Cards Would be Used More If Tax Incentives for Credit Card Use Were Introduced: Samsung Card's Survey to 300 Customers,” Kyunghyang Shinmun, July 19, 1999. 
mum threshold and a maximum ceiling, and it also includes a sunset clause. Until 2002 , eligible income deductions were allowed at $10 \%$ of the amount of electronically traceable payments, including credit card or debit card payments exceeding $10 \%$ of total labor income in a taxable year, within the ceiling set at the lesser of 3 million (approximately US\$2,600) or $10 \%$ of total labor income. ${ }^{33}$ To avoid double deductions, insurance premiums paid to public insurance funds, including national health insurance, national employment insurance, and the national pension fund, and for commercial indemnity insurance, as well as tuition and entrance fees paid to public and private regular educational institutions, are excluded from the category of eligible electronically traceable payments. ${ }^{34}$ In addition, national and local taxes; utility payments, including electricity, water, telephone, television, heating and cooking fuel gas, and so on; and transactions abroad are excluded, as such payments are not typically underreported. ${ }^{35}$ However, medical expenses that exceed the deduction threshold under income tax law are included in an effort to reduce underreporting in medical service sectors.

Since TIETP was introduced in 1999, it has been revised a number of times. Its sunset clause has been extended every successive sunset year, thus leaving TIETP in effect. In addition, in 2001, TIETP was strengthened. The deduction rate was increased from $10 \%$ to $20 \%$, and the ceiling on deductions was also increased to the lesser of million or $20 \%$ of total labor income. In 2003, after overconsumption and credit card debt defaults had become social problems, the deduction rate for debit cards was increased to $30 \%$ to encourage the use of debit cards over credit cards. Starting in 2005, the government began to increase the deduction threshold. It went from $10 \%$ of total labor income to $15 \%$ in 2005 , to $20 \%$ in 2008 , and to $25 \%$ in 2010 . In 2010 , the deduction ceiling was lowered from $\$ 5$ million to $\$ 3$ million. The deduction rate for credit cards was also lowered, from $20 \%$ to $15 \%$ in 2013 . However, in 2012 and 2013, TIETP was expanded again when payments to vendors in traditional markets and for public transportation costs were added as eligible electronically traceable payments for nontax policy purposes. Table 6 , the information for which has been compiled from the National Laws and Regulation Database, summarizes the changes to TIETP made since 1999.

33. Article 126-2, Preferential Tax Control Law, effective as of August 31, 1999.

34. Article 121-2, presidential decree of Preferential Tax Control Law, effective as of October 30, 1999.

35. Ibid. 
Table 6. Changes to TIETP, 1999-2013

\begin{tabular}{|c|c|c|c|c|}
\hline Year & $\begin{array}{l}\text { Eligible } \\
\text { Electronically } \\
\text { Traceable Payments }\end{array}$ & $\begin{array}{l}\text { Deduction } \\
\text { Rate }\end{array}$ & $\begin{array}{l}\text { Threshold } \\
\text { for TIETP }\end{array}$ & Deduction Ceiling \\
\hline \multirow{2}{*}{1999} & credit cards & \multirow{2}{*}{$10 \%$} & \multirow{2}{*}{$\begin{array}{l}10 \% \times \text { total labor } \\
\text { income }\end{array}$} & \multirow{2}{*}{$\begin{array}{l}\text { Min(10\% } \\
\text { × TLI,W } 3 \text { million) }\end{array}$} \\
\hline & debit cards & & & \\
\hline 2001 & debit cards & $20 \%$ & $\begin{array}{l}10 \% \times \text { total labor } \\
\text { income }\end{array}$ & $\begin{array}{l}\text { Min(20\% } \\
\times \text { TLI,W } 5 \text { million) }\end{array}$ \\
\hline \multirow{2}{*}{2003} & credit cards & $20 \%$ & \multirow{2}{*}{$\begin{array}{l}10 \% \times \text { total labor } \\
\text { income }\end{array}$} & \multirow{2}{*}{$\begin{array}{l}\text { Min(20\% } \\
\times \text { TLI,W } 5 \text { million) }\end{array}$} \\
\hline & debit cards & $30 \%$ & & \\
\hline \multirow{3}{*}{2004} & credit cards & \multirow{3}{*}{$20 \%$} & \multirow{3}{*}{$\begin{array}{l}10 \% \times \text { total labor } \\
\text { income }\end{array}$} & \multirow{3}{*}{$\begin{array}{l}\text { Min(20\% } \\
\times \text { TLI,W } 5 \text { million) }\end{array}$} \\
\hline & debit cards & & & \\
\hline & $\begin{array}{l}\text { bearer-identifiable } \\
\text { prepaid cards }\end{array}$ & & & \\
\hline 2005 & $\begin{array}{l}\text { electronically traceable } \\
\text { cash receipts added }\end{array}$ & $20 \%$ & $\begin{array}{l}15 \% \times \text { total labor } \\
\text { income }\end{array}$ & $\begin{array}{l}\text { Min(20\% } \\
\times \text { TLI,W } 5 \text { million) }\end{array}$ \\
\hline 2006 & $\begin{array}{l}\text { electronically traceable } \\
\text { cash receipts }\end{array}$ & $15 \%$ & $\begin{array}{l}15 \% \times \text { total labor } \\
\text { income }\end{array}$ & $\begin{array}{l}\text { Min(20\% } \\
\times \text { TLI,W } 5 \text { million) }\end{array}$ \\
\hline 2008 & $\begin{array}{l}\text { electronically traceable } \\
\text { cash receipts }\end{array}$ & $20 \%$ & $\begin{array}{l}20 \% \times \text { total labor } \\
\text { income }\end{array}$ & $\begin{array}{l}\operatorname{Min}(20 \% \\
\times \text { TLI,W } 5 \text { million })\end{array}$ \\
\hline \multirow{3}{*}{2010} & credit cards & $20 \%$ & \multirow{3}{*}{$\begin{array}{l}25 \% \times \text { total labor } \\
\text { income }\end{array}$} & \multirow{3}{*}{$\begin{array}{l}\operatorname{Min}(20 \% \\
\times \text { TLI,W } 3 \text { million) }\end{array}$} \\
\hline & $\begin{array}{l}\text { debit cards, bearer- } \\
\text { identifiable prepaid cards }\end{array}$ & $25 \%$ & & \\
\hline & $\begin{array}{l}\text { electronically traceable } \\
\text { cash receipts }\end{array}$ & $20 \%$ & & \\
\hline \multirow{4}{*}{2012} & credit cards & $20 \%$ & \multirow{4}{*}{$\begin{array}{l}25 \% \times \text { total labor } \\
\text { income }\end{array}$} & \multirow{4}{*}{$\begin{array}{l}\text { Min( } 20 \% \\
\times \text { TLI,W } 3 \text { million) }\end{array}$} \\
\hline & $\begin{array}{l}\text { debit cards, bearer- } \\
\text { identifiable prepaid cards }\end{array}$ & $30 \%$ & & \\
\hline & $\begin{array}{l}\text { electronically traceable } \\
\text { cash receipts }\end{array}$ & $20 \%$ & & \\
\hline & traditional market use & $30 \%$ & & \\
\hline
\end{tabular}




\begin{tabular}{|c|c|c|c|c|}
\hline Year & $\begin{array}{l}\text { Eligible } \\
\text { Electronically } \\
\text { Traceable Payments }\end{array}$ & $\begin{array}{l}\text { Deduction } \\
\text { Rate }\end{array}$ & $\begin{array}{l}\text { Threshold } \\
\text { for TIETP }\end{array}$ & Deduction Ceiling \\
\hline \multirow{5}{*}{2013} & credit cards & $15 \%$ & \multirow{5}{*}{$\begin{array}{l}25 \% \times \text { total labor } \\
\text { income }\end{array}$} & \multirow{5}{*}{$\begin{array}{l}\text { Min( } 20 \% \\
\text { xTLI,W } 3 \text { million) }\end{array}$} \\
\hline & $\begin{array}{l}\text { debit cards, bearer- } \\
\text { identifiable prepaid cards }\end{array}$ & $30 \%$ & & \\
\hline & $\begin{array}{l}\text { electronically traceable } \\
\text { cash receipts }\end{array}$ & $30 \%$ & & \\
\hline & traditional market use & $30 \%$ & & \\
\hline & public transportation use & $30 \%$ & & \\
\hline
\end{tabular}

\section{The TIETP Process}

Wage earners eligible for tax deductions for credit card payments may submit to the National Tax Service, via their employers, the credit card tax deduction application form and a credit card transaction report issued by their credit card companies. These materials must accompany the wage earners' labor income tax filing from the end of the tax year. Credit card companies may voluntarily issue credit card transaction reports to their customers, or they may issue them upon request. ${ }^{36}$ After TIETP was introduced, credit card companies began voluntarily sending their customers annual transaction reports at the end of the tax year as a customer service. In 2000, when TIETP was fully implemented, the Act on the Submission and Management of Taxation Data became law. According to the act, credit card companies must regularly submit member stores' credit card and debit card transaction data to the National Tax Service. As of 2012, wage earners can claim TIETP tax deductions by confirming prefilled credit card transactions data forms provided by the National Tax Service through its Home Tax Service, the National Tax Service tax service internet portal, which was created as per the terms of the act.

If the credit card tax deduction application is valid, employers, acting as the withholding tax agents of wage earners' income, subtract the taxes saved by TIETP together with other tax deductions and credits from the tax due in the month following the year-end tax settlement. ${ }^{37}$ If the withholding tax agents should refund overpaid taxes, they can subtract the refund amount from the taxes due in subsequent months or

36. Ibid.

37. Article 201, presidential decree of Income Tax Law; article 93, Ministry of Strategy and Finance order for Income Tax Law. 
request a refund from the regional National Tax Service office. ${ }^{38}$

The TIETP process differs completely from the receipt compensation process adopted in 1977. People who wanted to receive receipt compensation had to fill out a cumbersome application. They had to collect their receipts and take them to a regional National Tax Service office or commercial bank commissioned to deal with receipt compensation. Since compensations came out of an allotted budget, consumers often could not get their compensation due to delayed budget allocations or budget shortfalls. The TIETP application and refund process, in contrast, is easy and simple. The tax deduction is credited to wage earners' income taxes along with other tax deductions and credits, so refunds due are not delayed or declined. In addition, applicants do not need to collect all the credit card receipts, as credit companies issue aggregate annual transaction reports, and now prefilled credit card transaction information is presented to taxpayers by the National Tax Service Home Tax Service.

\section{Expansion of Electronically Traceable Payments: Electronically Traceable Cash Receipts}

After the introduction of tax incentives for credit card use in 1999, Korea introduced electronically traceable cash receipts and made them an eligible form of electronic payment for TIETP in 2005. These receipts make even cash payments electronically traceable by the National Tax Service. People who for any reason prefer to pay in cash rather than using a credit card can ask retailers to issue these receipts to them. The consumer provides a resident registration number (Korean citizens' ID number), a registered mobile phone number, or a credit or debit card number for personal identification purposes; the retailer then issues the electronically traceable cash receipt through its credit card payment terminal. Transaction data is automatically relayed to the National Tax Service. End consumers do not need to collect these receipts to receiver their income tax deduction; the National Tax Service provides electronically traceable cash receipt transaction data to wage earners, together with credit card and debit card transaction information, through the Home Tax Service portal. Wage earners just confirm their prefilled electronically traceable cash receipt, credit card, and debit card transaction data and submit the TIETP application to their employers.

\section{Expansion to Mobile Transactions}

TIETP also allows the purchase of goods and services by using credit cards and

38. Ibid. 
debit cards on a mobile phone even without an app. Therefore, business-to-consumer mobile phone transactions in Korea now fall into the TIETP category. In addition, the National Tax Service has made efforts to reinforce its mobile tax service. Since 2005, the National Tax Service has provided a mobile tax-related certificate issuing service, covering a range of documents, such as business registration certificates, tax payment certificates, and business closure certificates. ${ }^{39}$ In 2014, the National Tax Service started a mobile newsletter service offering tax news, tax return and payment notifications, and information on tax legislation and rulings. 40 In 2015, the National Tax Service began providing a mobile Home Tax Service allowing taxpayers to issue electronically traceable cash receipt and e-invoices and to receive other tax-related services, including tax returns, tax inquiries, tax certifications, and the tax news service on their mobile phones. ${ }^{41}$

\section{TIETP PERFORMANCE EVALUATION}

This section investigates whether incentive measures encouraging end consumers to use electronically traceable payments help reduce underreporting in cash-intensive retail sectors. First, as a descriptive analysis, we examine the volume of electronically traceable payments, the taxpayer ratio as a percentage of business income earners, and effective personal income tax rates in Korea, which provide broad evidence for reductions in underreporting. We then estimate TIETP's quantitative tax revenue effects using counterfactual analysis.

\section{Descriptive Analysis for TIETP}

\section{Increase in Electronically Traceable Payments}

TIETP allows wage and salary income earners to claim tax deductions for their credit card, debit/check card, and bearer-identifiable prepaid card spending, which is believed to have substantially increased the number of cashless payments since its introduction in 1999. Figure 4 shows the volume of electronically traceable payments

39. "Mobile Tax Certificates Service Launch," National Tax Service press release, December 27, 2005.

40. "NTS Mobile Newsletter Service Launch," National Tax Service press release, July 21, 2014.

41. "User Friendly Mobile NTS App Service Launch,” National Tax Service press release, October 29, 2015. 
as a percentage of GDP from 1991 to 2014. Credit card transactions increased very sharply immediately after TIETP's introduction in 1999. They had been merely $4.9 \%$ in 1999 , but they had skyrocketed to $34.3 \%$ by 2002. In absolute terms, electronically traceable payments soared from $\$ 28.5$ trillion (approximately US\$26 billion) to \#261.7 trillion (approximately US\$238 billion) during the same period.

Since 2003, when the government increased the TIETP deduction rate for debit cards increased from $20 \%$ to $30 \%$ to encourage their use over credit cards, debit card payments have risen sharply. In 2005, the electronically traceable cash receipt was made eligible for TIETP. These changes, seem to have induced consumers to switch to these alternative methods of payment, moderating the increase of credit card transactions since 2003, as shown in figure 4, which is based on our aggregation of data from Bank of Korea.

Figure 4. Credit, Debit, and Prepaid Card Transactions as Percentage of GDP

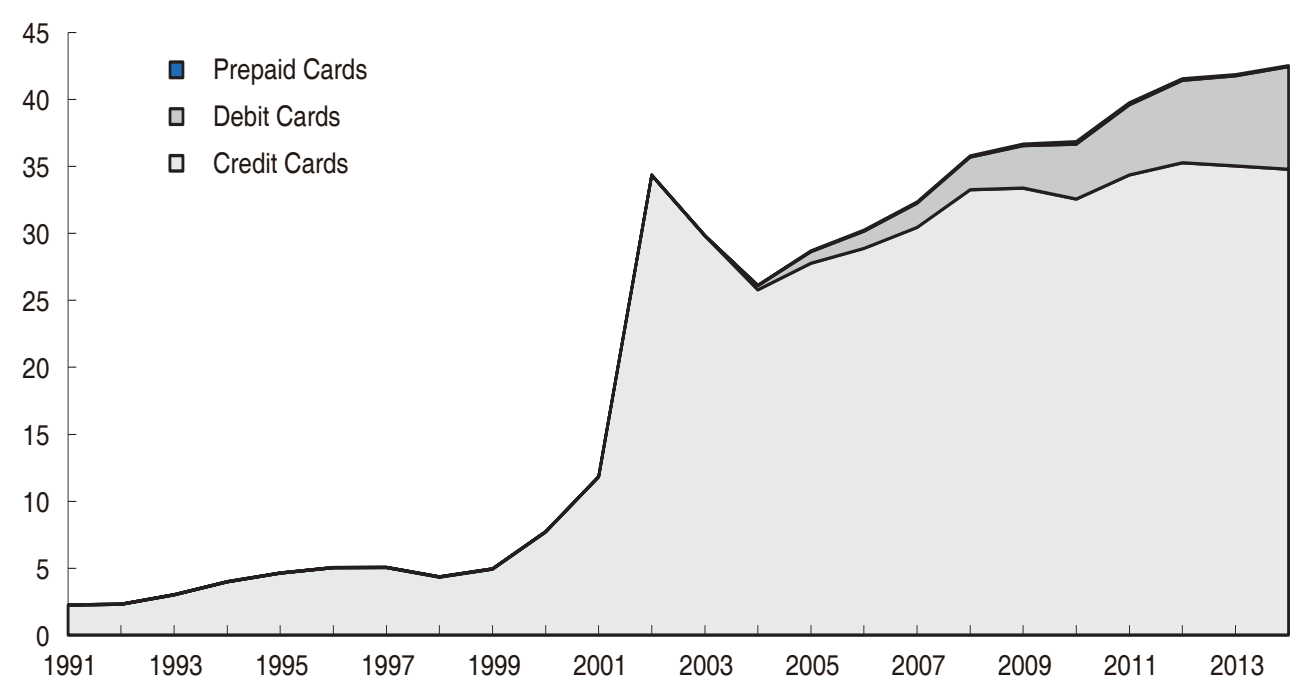

Source: Authors' aggregation of data from Bank of Korea (http://ecos.bok.or.kr).

Notes: a. Debit card payments include check cards. b. Electronically traceable cash receipt payments are not included. c. Payments by all consumers, including not only wage and salary income earners but also self-employed businesses.

In 2014, the total value of credit, debit, check, and prepaid cards, not including electronically traceable cash receipts, reached $\$ 631.6$ trillion (approximately US\$574 billion), 42.5\% of GDP. Since 2005, card payments as a ratio to GDP in Korea have ranked highest among the 23 member countries of the Committee of Payments and 
Market Infrastructures, Bank for International Settlements. ${ }^{42}$

If electronically traceable cash receipt payments (\$91.9 trillion in 2014) are included, electronically traceable payments as a ratio of GDP is around $49 \%$ for 2014. ${ }^{43}$ The data used for figure 4 does not include electronically traceable payments, but it does include check cards and represents payments by all consumers, including not only wage and salary income earners but also self-employed businesses.

Table 7. Electronically Traceable Payments as Percentage of Private Final Consumption Expenditure

\begin{tabular}{|c|c|c|c|c|c|c|c|c|c|c|c|c|}
\hline \multicolumn{2}{|c|}{ Year } & 2005 & 2006 & 2007 & 2008 & 2009 & 2010 & 2011 & 2012 & 2013 & 2014 & 2015 \\
\hline \multicolumn{2}{|c|}{$\begin{array}{l}\text { Private Final Consumption } \\
\text { Expenditure }(\Theta)\end{array}$} & 480.2 & 509.9 & 546.4 & 579.1 & 594.9 & 636.7 & 679.1 & 707.6 & 727.8 & 748.2 & 771.2 \\
\hline \multirow{5}{*}{$\begin{array}{l}\text { Electronically } \\
\text { Traceable } \\
\text { Payments }\end{array}$} & $\begin{array}{l}\text { credit } \\
\operatorname{card}(\ominus)\end{array}$ & 190.5 & 214.8 & 241.1 & 279.3 & 303.9 & 350.7 & 398.5 & 451.3 & 441.7 & 453.9 & 503.6 \\
\hline & $\begin{array}{l}\text { check } \\
\operatorname{card}(\circledast)\end{array}$ & 7.8 & 12.7 & 18.8 & 27.9 & 36.7 & 51.5 & 66.9 & 82.8 & 92.7 & 112.7 & 131.5 \\
\hline & $\begin{array}{l}\text { cash } \\
\text { receipt (4)) }\end{array}$ & 18.6 & 30.6 & 50.2 & 61.5 & 68.7 & 76.0 & 80.9 & 82.4 & 85.5 & 91.7 & 96.6 \\
\hline & $\begin{array}{l}\text { National } \\
\text { taxes, etc. (5)) }\end{array}$ & .. &.. & .. & .. & .. & .. & 8.1 & 19.2 & 18.9 & 22.6 & 46.3 \\
\hline & $\begin{array}{l}\operatorname{sum}(5)=\ominus+ \\
\circledast+(4)-(5))\end{array}$ & 216.9 & 258.1 & 310.1 & 368.7 & 409.3 & 478.2 & 538.2 & 597.3 & 601.0 & 635.7 & 685.4 \\
\hline \multicolumn{2}{|l|}{ Ratio ( (5)/ $\ominus$ ) } & $45.2 \%$ & $50.6 \%$ & $56.8 \%$ & $63.7 \%$ & $68.8 \%$ & $75.1 \%$ & $79.3 \%$ & $84.4 \%$ & $82.5 \%$ & $85.0 \%$ & $88.9 \%$ \\
\hline
\end{tabular}

Source: Ministry of Strategy and Finance.

Note: $\cdot \cdot=$ negligible.

Table 7 shows the increase in electronically traceable payments as compared to private final consumption expenditure, which the Ministry of Strategy and Finance put together from private final consumption expenditure data (Bank of Korea), credit card and check card payments (the Credit Finance Association), debit card payments (Bank of Korea), and cash receipts (National Tax Service). Business card payments were

42. Card payments (not including e-money) as a ratio to GDP was $30.5 \%$ in $2005,36.7 \%$ in 2010 , and $42.5 \%$ in 2014 . Data retrieved from statistics on payment, clearing, and settlement systems in countries that are members of the Committee on Payments and Market Infrastructures.

43. Electronically traceable credit card payments totaled $\$ 18.6$ trillion in 2005 , 76.0 trillion in 2010, and 91.0 trillion in 2014. Data retrieved from Statistical Yearbook of National $\operatorname{Tax}$ (NTS 2006-2015). 
subtracted from credit card and check card payments and national taxes, and four national insurance premiums paid by credit cards were subtracted from electronically traceable payments. The proportion of these payments compared to private final consumption expenditure increased from $45.2 \%$ in 2005 to $88.9 \%$ in 2015 . The absolute majority of private consumption, other than indispensable cash transactions, are now paid with electronically traceable payments in Korea, which brings the country near to having a cashless society.

\section{Increased Tax Net for Business Income}

In many countries, business income earned by the self-employed is more frequently underreported than is wage and salary income, due to the lack of third-party information accessible to tax authorities (Pissarides \& Weber 1989; Lyssiotou, Pashardes, \& Stengos 2004; Gërxhani 2004; Wangen 2005; Martinez-Lopez 2012). Korea is no exception. According to Sung (1999, p.69), between 1994 and 1998, before the introduction of TIETP, only about half of business income earned by the self-employed was reported to the National Tax Service. Such low tax compliance among owner-operated businesses often led to a low number of active taxpayers as a percentage of relevant income earners.

Figure 5. Personal Income Taxpayers as Percentage of Relevant Income Earners (\%)

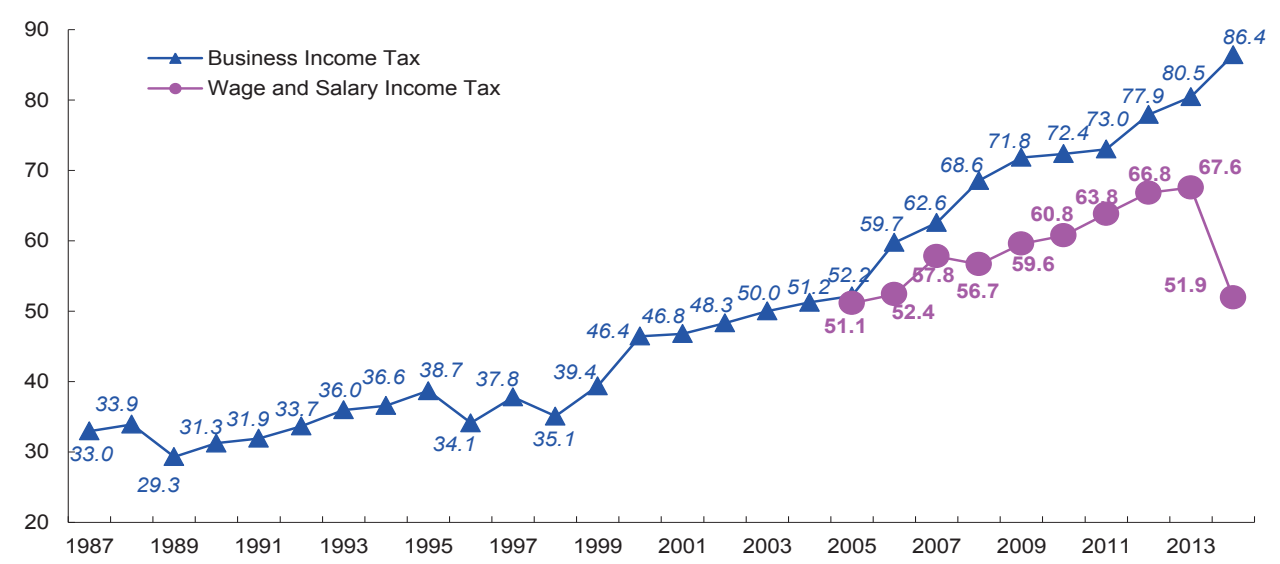

Source: Authors' calculation based on Statistical Yearbook of National Tax (National Tax Service, 19882015).

Note: The ratio of wage and salary income to taxpayers decreased dramatically in 2014 due to changes in the personal income tax income deduction system in 2014. The income deduction for education expenses, medical expenses, private insurance premiums, and charity contributions were shifted to tax credits, which made many marginal taxpayers tax exempt. 
As shown in figure 5, the ratio of taxpayer to business income earners in Korea lingered aground 30\% from early 1980s to the mid-1990s, but it began to increase gradually and substantially from the late 1990 s onward. It rose to about $50 \%$ in the early 2000 s and dramatically to $86.4 \%$ in 2014 . Such an upward trend in the business income could be attributable to higher nominal income due to economic growth and, in some part, to inflation (the inflation rate is low in Korea and thus has a moderate effect). Since Korea has increased the personal income tax exemption threshold only once, in 2008 (from $\$ 10$ million to $\$ 12$ million), after introducing TIETP in 1999, and since it does not adopt inflation-adjusted personal income tax brackets, income increases may result in a higher active taxpayer ratio. However, given the economic growth and inflation effects at all times, it seem more likely that TIETP is the cause of the upward trend.

\section{Effective Personal Income Tax Rate for Owner-Operated Businesses}

The effective personal income tax rates are estimated through microsimulation analysis developed by Sung (2008) using Household Income and Expenditure Survey data, a household survey data set, collected monthly and compiled, and released by Statistics Korea every quarter year. This data provide monthly and quarterly income and expenditures, along with each household's demographic characteristics, that can be used to estimate household personal income tax. Detailed personal income tax estimation methods using the Household Income and Expenditure Survey and summary statistics of the survey are attached in appendixes 1 and 2.

Figure 6, drawing on the Household Income and Expenditure Survey (Statistics Korea, 1982-2014), illustrates the longitudinal changes of effective personal income tax rates both for self-employed business income and wage and salary income for the last three decades. The two effective personal income tax rates have different trends. The effective personal income tax rate of wage and salary income increased from $1.6 \%$ to $4.0 \%$ from 1982 to 1988 and then oscillated within the range of $2.2 \%$ to $3.5 \%$ from 1989 until recently. For business income, the effective personal income tax rate decreased from $5.6 \%$ to $3.4 \%$ from 1982 to 1998 but turned to a continuous upward trend from $3.4 \%$ in 1998 to $6.3 \%$ in 2013 after the introduction of TIETP, except for the two dips caused by Korea's economic crises in 2002-2003 and 2008-2009. 
Figure 6. Effective Personal Income Tax Rate for Business Income and Wage and Salary Income (\%)

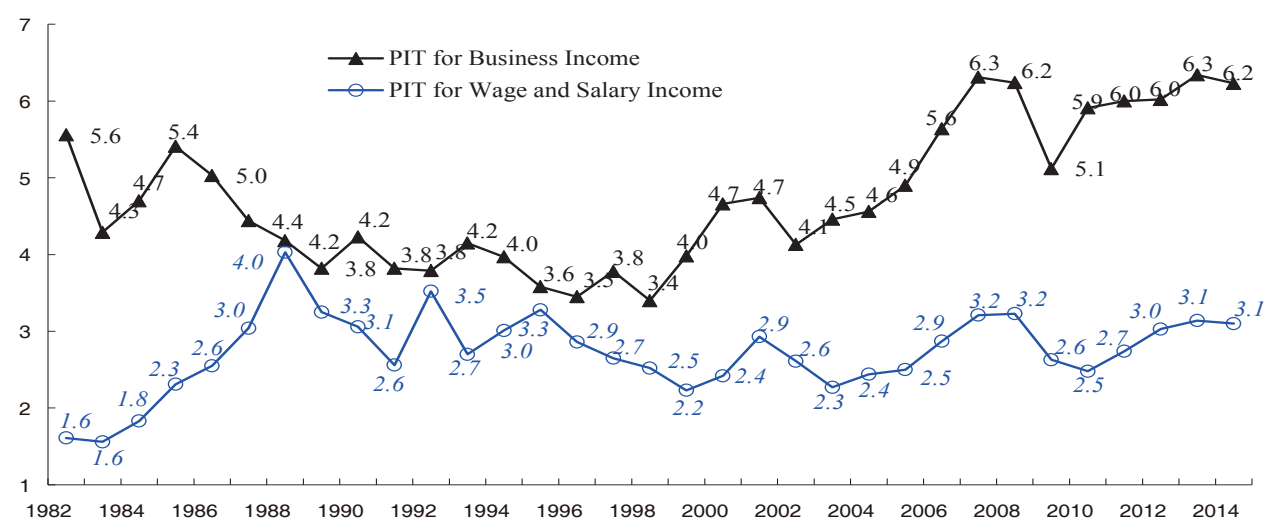

Source: Author's estimation using Household Income and Expenditure Survey (Statistics Korea, 19822014).

These two different trends since 1999 show that TIETP contributed to the broadening tax base for self-employed businesses while it alleviated wage and salary earners' tax burdens. Since the introduction of TIETP in 1999, wage and salary earners have actively used credit cards to get the tax incentives and, as a result, self-employed business income earners have reported their business income more honestly, mindful that third parties were reporting transactions to the tax authorities. These trends give broad support to the theoretical framework - the TIETP-induced equilibrium change from "does not use credit card-does not report" to "uses credit card-reports"- discussed in the previous section. It should be noted, however, that just as in the case of the active taxpayer ratio, the upward trend in the effective personal income tax rate of business income may be a function of nominal income increases due to economic growth and inflation, fixed income tax brackets, and personal income tax exemption thresholds. However, such creeping effects might not have been realized automatically without TIETP, because business owners tend to underreport business income to offset such effects.

One notable phenomenon in this personal income tax rate trend is that the effective personal income tax rate of business income is greater than that of wage and salary income, without exception, for the whole period considered. This runs against the common understanding that self-employed workers' business income tends to be underreported. One possible interpretation is that the Korean personal income tax system allows more generous income deductions to wage and salary earners because wage and salary earners' incomes are correctly reported by third parties, while 
self-employed workers' business income is underreported in the absence of third-party information. Another interpretation is that the average income of the self-employed is greater than that of employed workers, and as a result the self-employed are subject to a higher progressive income tax schedule.

\section{Quantitative Analysis for TIETP}

\section{Methodology and Data}

TIETP's effects were analyzed using microsimulation methods through counterfactual analysis adopted by Song and Sung (2012). This study updates the Song and Sung (2012) approach, using 2014 the Household Income and Expenditure Survey data set. Three different scenarios were set up to evaluate policy effects by establishing the counterfactual and the observable. When we estimated true business income in each scenario, we adjusted income data obtained from Household Income and Expenditure Survey on the assumption that it was also underreported, as in tax reporting. ${ }^{44}$ Real business incomes were estimated by comparing the income and expenditures of self-employed workers with those of wage and salary earners. The ratio of business income reported to tax authorities over real business income as of 2014 was estimated by applying the same method employed in Sung (1999, 2008). Business income reported to tax authorities per household was estimated with the real business income and income reporting ratio obtained in the previous step. The personal income tax burden was calculated based on the business income reported to tax authorities as well as demographics and expenditure data obtained from Household Income and Expenditure Survey. However, it was assumed that wage and salary income were reported correctly. The detailed methodology is described in the appendix 2. Following are the three scenarios employed.

Scenario A (counterfactual scenario 1: baseline): Average personal income tax burden per household in 2014 was estimated under the assumption that business income earners reported their income based on the past increasing trend without the intervention of TIETP. The average reported business income in 2014 was estimated by extrapolating the past ratio of business income earners' reported income to their real income. In this study, Sung's estimate (1999) for the ratio of business income earners' reported income to real income in 1996 (47.7\%) and another Sung estimate

44. Hurst, Li, and Pugsley 2014 show that in U.S. household surveys the self-employed systematically underreport their income by about $25 \%$. 
(2008) for 2001 (53.9\%) were used to linearly extrapolate the estimate for 2014. ${ }^{45} \mathrm{We}$ specifically used the 2001 estimate for extrapolation because the estimates between 1997 and 2000 were outliers due to the financial crisis in Korea and because if the 2001 estimate affected by TIETP at the early stages of TIETP introduction was extrapolated as a baseline, it would underestimate the effect of TIETP when compared to the observable. In other words, considering that the extrapolation using inflated data would result in a conservative estimate of the TIETP effect, we compromised by using the 2001 estimate.

It was assumed that this counterfactual scenario only included tax-base-broadening effects caused by factors other than TIETP. Those factors could be taxpayers' voluntary compliance, tax authorities' tax enforcement efforts, or other unknown socioeconomic changes. Therefore, this counterfactual scenario reflected all causal factors other than TIETP, thus differentiating them from TIETP effects.

Scenario B (counterfactual scenario 2): The average personal income tax burden per household in 2014 was estimated under the assumption that TIETP is in effect but has not led to tax losses. The average reported business income was estimated by applying the ratio of reported business income to real business income, which reflected the base-broadening effects of TIETP. However, when estimating the personal income tax burden, contrary to the facts, tax forgone by the underwriting of TIETP was not factored in. Accordingly, this scenario shows the gross effect of TIETP's base broadening as of 2014 under the assumption that the same tax-base-broadening effects caused by TIETP were realized without tax revenue loss.

Scenario C (observable scenario): The average personal income tax burden per household in 2014 was estimated under the current personal income tax law, as of 2014, which includes TIETP. Tax forgone was also factored in when calculating the average personal income tax burden.

The comparison among these scenarios shows how much TIETP broadened the tax base and increased tax revenue on average in 2014 and how much tax revenue was forgone to finance TIETP. The difference between scenarios A and B $(\Theta)$ illustrates the gross base-broadening effect of TIETP on tax revenue. The difference between scenarios $\mathrm{B}$ and $\mathrm{C}(\ominus)$ reveals the revenue cost to finance TIETP. The gap between the two differences $(\ominus-\ominus)$ is the net gain of TIETP. TIETP is justified only if its net gain is positive.

45. When the two data points $\left(Y t_{1}, t_{1}\right)$ and $\left(Y t_{2}, t_{1}\right)$ are given, the linear extrapolation function is be $\mathrm{Y}\left(t^{*}\right)=\frac{Y t 2-Y t 1}{t 2-t 1} \times\left(t^{*}-t 1\right)+\mathrm{Y} t t_{1}$. In our case, it is $\mathrm{Y}\left(t^{*}\right)=1.24 t^{*}-2427.34$. Therefore, the reported income to real income ratio in 2014 was $\mathrm{Y}(2014)=70.1(\%)$. 


\section{Tax Revenue Effects of TIETP}

Table 8 illustrates the average income and personal income tax estimation per household by decile as of 2014, which we have estimated using data from the Household Income and Expenditure Survey 2014. The first nine rows display the distributions of the average income, personal income tax burdens, and the revenue effects of TIETP by decile as of 2014. The next six rows indicate the relative ratios of each income and personal income tax to gross income. The following three rows indicate the ratios of personal income tax burdens to wage and salary income or business income, that is, the effective personal income tax rates. The last six rows indicate the shares of each income and personal income tax by decile.

Gross revenue effects of TIETP, the difference between scenarios B and A ranges from $\$ 3,000$ to $\$ 704,000$ by decile. Tax forgone to finance TIETP, the difference between scenarios B and C ranges from $\$ 0$ to $\$ 317,000$. Therefore, net gains of TIETP range from $\$ 3,000$ to $\$ 387,000$. On average, gross revenue effects of TIETP are $\$ 186,000$; the cost of TIETP is $\$ 108,000$ and the net effect is $\$ 78,000$. In sum, TIETP is quite costly but still yields positive tax revenue increases.

Figure 7 graphically shows these revenue effects. Net gains in the personal income tax burden increase as income does. The net gain curve is upward at an accelerating rate. In particular, revenue gains in 10th docile are striking. TIETP increases the personal income tax burden of higher income earners more than that of lower income earners, although it gives more tax relief to them.

Table 8. Distribution of Average Income and Personal Income Tax Burden per Household by Gross Income Decile

\begin{tabular}{|c|c|c|c|c|c|c|c|c|c|c|c|c|}
\hline \multicolumn{2}{|l|}{ (Thousand $W$ ) } & 1st & 2nd & 3rd & 4th & 5 th & 6th & 7 th & 8th & 9th & 10th & Avg. \\
\hline \multicolumn{2}{|l|}{ Market Income } & 6,425 & 13,526 & 20,948 & 28,186 & 34,946 & 40,503 & 49,322 & 58,353 & 71,975 & 106,312 & 43,046 \\
\hline \multicolumn{2}{|l|}{ Gross Income } & 10,456 & 18,383 & 25,769 & 32,866 & 39,752 & 46,557 & 54,083 & 63,508 & 77,086 & 112,455 & 48,088 \\
\hline \multicolumn{2}{|c|}{$\begin{array}{l}\text { Wage/ Salary } \\
\text { and Business Income }\end{array}$} & 3,584 & 9,749 & 17,087 & 24,215 & 31,906 & 37,690 & 46,463 & 54,889 & 68,011 & 99,601 & 39,316 \\
\hline \multirow{3}{*}{$\begin{array}{l}\text { Personal } \\
\text { Income } \\
\text { Tax }\end{array}$} & scenario $\mathrm{A}$ & 10 & 72 & 191 & 378 & 698 & 1,015 & 1,500 & 2,437 & 3,741 & 8,670 & 1,871 \\
\hline & scenario B & 13 & 88 & 235 & 454 & 812 & 1,175 & 1,694 & 2,678 & 4,057 & 9,374 & 2,057 \\
\hline & scenario C & 13 & 83 & 224 & 428 & 739 & 1,074 & 1,566 & 2,500 & 3,816 & 9,057 & 1,949 \\
\hline \multirow{3}{*}{$\begin{array}{l}\text { Wage/ Salary } \\
\text { and Business } \\
\text { Income }\end{array}$} & GE (B-A) & 3 & 16 & 44 & 76 & 114 & 160 & 194 & 241 & 316 & 704 & 186 \\
\hline & TF (C-B) & 0 & -5 & -11 & -26 & -73 & -101 & -128 & -178 & -241 & -317 & -108 \\
\hline & \begin{tabular}{|l|} 
net effect \\
(gross effect \\
+ tax revenue \\
foregone)
\end{tabular} & 3 & 11 & 33 & 50 & 41 & 59 & 66 & 63 & 75 & 387 & 78 \\
\hline
\end{tabular}




\begin{tabular}{|c|c|c|c|c|c|c|c|c|c|c|c|c|}
\hline \multicolumn{2}{|c|}{$\begin{array}{l}\text { Ratios to Gross } \\
\text { Income (\%) }\end{array}$} & 1st & 2nd & $3 r d$ & 4th & 5 th & 6th & 7th & 8th & 9th & 10th & Avg. \\
\hline \multicolumn{2}{|c|}{ Market Income } & 61.45 & 73.58 & 81.29 & 85.76 & 87.91 & 87 & 91.2 & 91.88 & 93.37 & 94.54 & 89.52 \\
\hline \multicolumn{2}{|c|}{ Gross Income } & 100 & 100 & 100 & 100 & 100 & 100 & 100 & 100 & 100 & 100 & 100 \\
\hline \multicolumn{2}{|c|}{$\begin{array}{l}\text { Wage/ Salary } \\
\text { and Business Income }\end{array}$} & 34.28 & 53.04 & 66.31 & 73.68 & 80.26 & 80.95 & 85.91 & 86.43 & 88.23 & 88.57 & 81.76 \\
\hline \multirow{3}{*}{$\begin{array}{l}\text { Personal } \\
\text { Income } \\
\text { Tax }\end{array}$} & scenario $\mathrm{A}$ & 0.1 & 0.39 & 0.74 & 1.15 & 1.76 & 2.18 & 2.77 & 3.84 & 4.85 & 7.71 & 3.89 \\
\hline & scenario B & 0.13 & 0.48 & 0.91 & 1.38 & 2.04 & 2.52 & 3.13 & 4.22 & 5.26 & 8.34 & 4.28 \\
\hline & scenario $\mathrm{C}$ & 0.12 & 0.45 & 0.87 & 1.3 & 1.86 & 2.31 & 2.9 & 3.94 & 4.95 & 8.05 & 4.05 \\
\hline \multicolumn{2}{|c|}{$\begin{array}{l}\text { Ratios to Wage/ } \\
\text { Salary and Business } \\
\text { Income (\%) }\end{array}$} & $1 s t$ & 2nd & $3 \mathrm{rd}$ & 4th & 5 th & 6th & 7 th & 8th & 9th & 10th & Avg. \\
\hline \multirow{3}{*}{$\begin{array}{l}\text { Personal } \\
\text { Income } \\
\text { Tax }\end{array}$} & scenario $\mathrm{A}$ & 0.29 & 0.74 & 1.12 & 1.56 & 2.19 & 2.69 & 3.23 & 4.44 & 5.5 & 8.71 & 4.76 \\
\hline & scenario B & 0.37 & 0.9 & 1.37 & 1.88 & 2.54 & 3.12 & 3.65 & 4.88 & 5.97 & 9.41 & 5.23 \\
\hline & scenario C & 0.35 & 0.85 & 1.31 & 1.77 & 2.32 & 2.85 & 3.37 & 4.55 & 5.61 & 9.09 & 4.96 \\
\hline \multicolumn{2}{|c|}{ Shares by Decile (\%) } & 1st & 2nd & 3 rd & 4th & 5 th & 6 th & 7 th & 8th & 9th & 10th & Total \\
\hline \multicolumn{2}{|c|}{ Market Income } & 1.49 & 3.14 & 4.87 & 6.55 & 8.12 & 9.41 & 11.46 & 13.56 & 16.72 & 24.7 & 100 \\
\hline \multicolumn{2}{|c|}{ Gross Income } & 2.17 & 3.82 & 5.36 & 6.83 & 8.27 & 9.68 & 11.25 & 13.21 & 16.03 & 23.39 & 100 \\
\hline \multicolumn{2}{|c|}{$\begin{array}{l}\text { Wage/ Salary } \\
\text { and Business } \\
\text { Income }\end{array}$} & 0.91 & 2.48 & 4.35 & 6.16 & 8.12 & 9.59 & 11.82 & 13.96 & 17.30 & 25.33 & 100 \\
\hline \multirow{3}{*}{$\begin{array}{l}\text { Personal } \\
\text { Income Tax }\end{array}$} & scenario $\mathrm{A}$ & 0.06 & 0.39 & 1.02 & 2.02 & 3.73 & 5.42 & 8.02 & 13.03 & 20.00 & 46.35 & 100 \\
\hline & scenario B & 0.06 & 0.43 & 1.14 & 2.21 & 3.95 & 5.71 & 8.23 & 13.02 & 19.72 & 45.56 & 100 \\
\hline & scenario C & 0.06 & 0.43 & 1.15 & 2.19 & 3.79 & 5.51 & 8.03 & 12.82 & 19.57 & 46.46 & 100 \\
\hline
\end{tabular}

Source: Authors' estimation using data from HIES 2014.

Figure 7. Tax Revenue Effects of TIETP per Household by Decile in 2014

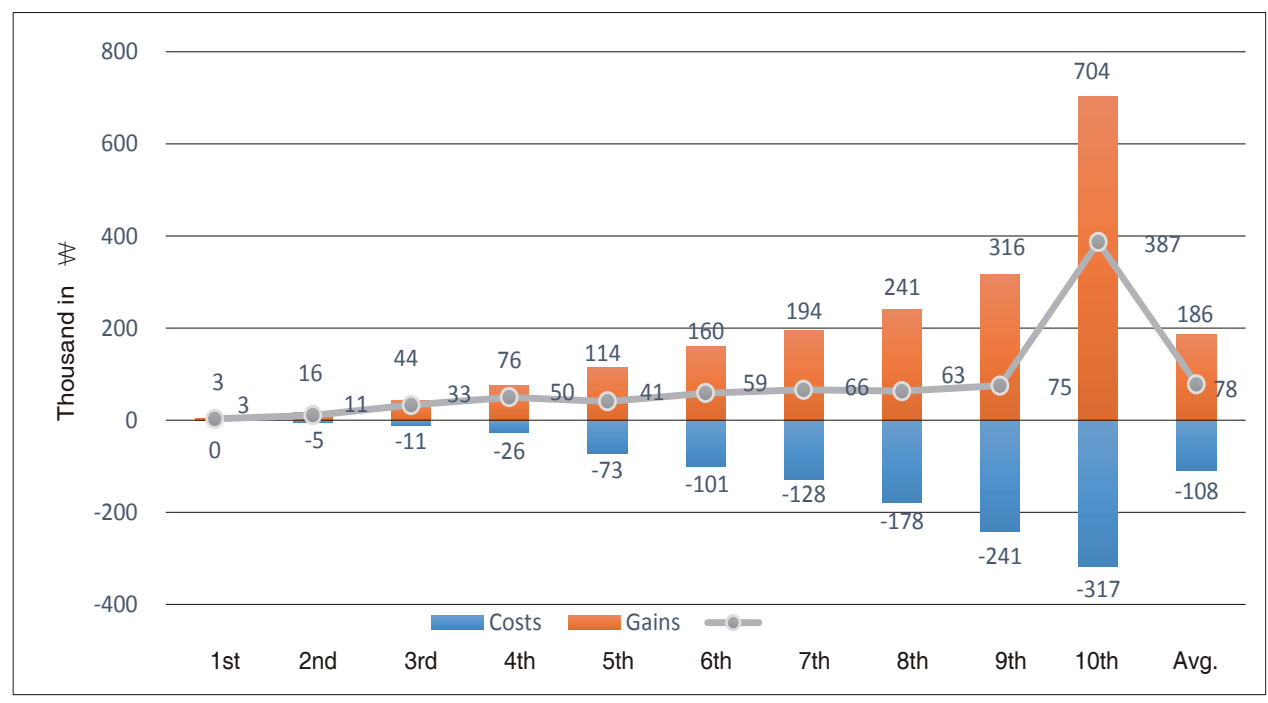

The Korean Journal of Policy Studies 
Table 9 shows the total personal income tax revenue effect, which was calculated by multiplying the average personal income tax burden per household and the total number of households $(18,001,541$ households in 2014). The total gross effect of TIETP was $\$ 3.4$ trillion, while the cost of TIETP reached $\$ 1.9$ trillion. The net gain was estimated at 1.4 trillion (approximately US\$1.3 billion), which increased personal income tax revenue by $4.2 \%$ as compared to baseline scenario A without the intervention of TIETP. If the revenue increase in VAT and corporate income tax were taken into account, the revenue impact of TIETP would be much larger.

Table 9. Total Personal Income Tax Revenue Impact of TIETP

\begin{tabular}{l|c|c|c}
\hline \multicolumn{2}{c|}{ Participation } & Avg. (Thousands in W) & Total (Billions in W) \\
\hline $\begin{array}{l}\text { Personal } \\
\text { Income Tax }\end{array}$ & scenario A & 1,871 & 33,675 \\
\cline { 2 - 4 } & scenario B & 2,057 & 37,036 \\
\hline \multirow{3}{*}{$\begin{array}{l}\text { Revenue } \\
\text { Effect }\end{array}$} & scenario C & 1,949 & 35,090 \\
\cline { 2 - 4 } & gross revenue effect (B-A) & 186 & $3,361(10.0 \%)$ \\
\cline { 2 - 4 } & $\begin{array}{c}\text { tax revenue forgone (C-B) } \\
\text { netfect (gross effect + tax } \\
\text { revenue forgone) }\end{array}$ & -108 & $-1,946(-5.8 \%)$ \\
\hline
\end{tabular}

Note: Numbers in parentheses under "revenue effect" indicate the percentage increase from the revenue in baseline scenario $A$.

\section{Effects on Tax Equality}

Table 10 shows changes in the Gini coefficient between gross income and gross income less personal income tax. Personal income tax under the baseline scenario A, without the intervention of TIETP, decreases the Gini coefficient from 0.3357 to 0.3230 by $-3.79 \%$. When TIETP is taken into account (as in scenario C), it decreases to 0.3227 by $-3.90 \%$. However, this enhancement of income redistribution is undermined by 0.14 percentage points (from $-4.04 \%$ to $-3.90 \%$ ) by the tax forgone to finance TIETP, which is unevenly given to higher income deciles due to the progressive tax structure. The Gini coefficient would decrease to 0.32216 by $-4.04 \%$ if the tax broadening effect of TIETP did not entail tax forgone. In sum, TIETP had a positive impact on income redistribution due to the broadened tax base, despite the greater tax relief given to higher income earners. The Gini coefficient decreased by 0.11 percentage points (from $-3.79 \%$ to $-3.90 \%$ ) This means that the tax-base-broadening effect of TIETP on income redistribution outweighs its negative effect on income redistribution 
caused by tax relief, and as a result it eventually enhances income redistribution.

Table 10. Changes of Gini Coefficients

\begin{tabular}{l|c|c|c}
\hline & Scenario A & Scenario B & Scenario C \\
\hline Market Income & 0.36942 & & \\
\hline Gross Income & 0.33574 & & 0.32265 \\
\hline $\begin{array}{l}\text { Gross Income Less Personal } \\
\text { Income Tax }\end{array}$ & 0.32303 & 0.32216 & -3.90 \\
\hline $\begin{array}{l}\text { \% Change between Gross Income } \\
\text { and Gross Income Less Personal } \\
\text { Income Tax }\end{array}$ & -3.79 & -4.04 & \\
\hline
\end{tabular}

\section{CONCLUSION}

TIETP incentivizes end consumers to pay electronically for their purchases, and at the same time, it induces owner-operated retail businesses to honestly report their incomes to tax authorities. To claim tax deductions, end consumers use electronic payments that are then automatically reported to tax authorities. It is equivalent to business buyers reporting their business sellers' sales to claim their input VAT credit in business-to-business transactions. Thus retail businesses whose sales are reported by third parties (the consumers) file truthful income tax returns; in fact, they are only required to confirm their electronically traceable sales on prefilled tax return forms provided by the National Tax Service if they find no errors. This paper shows that by incentivizing end consumers to make payments electronically TIETP is effective as a tool for reducing underreporting in cash-intensive retail businesses. In Korea, TIETP was successful in turning a predominantly cash economy into a largely cashless one, with a consequent considerable curtailment of the shadow economy, in a relatively short period of time.

Future implications and challenges for countries pursuing an incentive structure to induce electronic payment are as follows:

First, critical to TIETP's success is a legal framework and tax information system that enables tax authorities to gain access to and to analyze financial transaction information. It would not be possible for TIETP to induce retail businesses' voluntary compliance if tax authorities were unable to collect and process this information. Korea's 2000 Act on the Submission and Management of Taxation Data played a pivotal role 
in enabling tax authorities to gather electronic financial transaction information and in inducing voluntary tax compliance in cash-intensive business sectors. In addition, the National Tax Service established an integrated tax system in 1997 to integrate all transaction data obtained from electronically traceable payments, including credit cards, debit cards, cash receipts in business-to-consumer transactions, e-invoices in business-to-business transactions, financial income information, property transaction information, and other third-party information provided by public and private institutions. The National Tax Service now makes use of the system to verify taxpayers' tax returns and to analyze risk assessments and tax audits. The National Tax Service also uses the system to provide improved taxpayer services by making prefilled tax return forms and other tax payment guide services available.

Second, ensuring that the tax rebate process is easy and guarantees the rebate will be received are important success factors. The incentives given to end consumers to make electronic payments are relatively weak, so if the application process for the tax rebate is inconvenient or cumbersome, or if rebate payments are unreliable, people will be discouraged from using the system. Korea's VAT compensation for receipts, introduced in 1977, failed because it was inconvenient and the compensation was not assured; TIETP, by contrast, has been successful because it is convenient, the result of making electronic data processing and application processes part of existing year-end tax settlement processes. Wage and salary earners can easily file year-end personal income tax settlement returns with prefilled electronically traceable payment information provided by the National Tax Service and get TIETP tax refunds along with other tax credits due them.

Third, the size of tax incentives should be carefully set so that the revenue that is forgone by underwriting TIETP does not exceed the revenue increase gained. One way to do this is by setting thresholds and maximum ceilings for TIETP; another is by limiting what counts as eligible TIETPs. Sophisticated tax incentive structures would ensure net gain from TIETP.

Fourth, countries wishing to introduce similar tax incentives for electronic payments should consider their citizens' financial literacy and their financial sectors' technological preparedness. Developing countries pursuing a cashless economy may need to make considerable efforts to establish electronic payments among their citizens, especially those who regard cash payment as more convenient and secure than electronic payment (Nwankwo and Eze 2013). If a majority of a country's people are still heavily dependent on cash payments, either due to financial illiteracy, unfamiliarity with banking transactions, or lack of IT infrastructure in the financial sectors, TIETP should be introduced gradually, in line with the development of other relevant areas. In particular, in low-income developing countries where many people do not have access 
to the financial sector or credit cards, instituting TIETP for credit or check cards might be challenging. In this case, electronically traceable cash receipts could be an alternative, given that it does not require credit cards or bank accounts. Anyone who does not have a credit card or access to the financial system can pay with cash and make it electronically traceable by using a mobile phone number or electronically traceable cash receipt card registered to the tax authorities. Technological preparedness in retail sectors and financial sectors is still prerequisite, however.

Fifth, retail vendors' costs for installing electronic payment terminals and credit card payment fees that have to be paid to credit card companies can be a big challenge. If retail vendors are reluctant to install credit card payment terminals and accept credit cards due to high fees, increasing credit card payment will be difficult. As we have noted, the National Tax Service, supported by the 1999 Income Tax Law and VAT Law, made strong administrative recommendations encouraging vendors to become members of the credit card program. The Korean government strongly supported the lowering of credit card fees, which was justified in light of increasing credit card sales and the profits of credit card companies. ${ }^{46}$ In addition, tax credits for credit card sales by retail vendors, introduced in 1994, helped to relieve the burden on small retail vendors.

Sixth, tax policy makers should carefully design the tax incentive structure, keeping in mind the distortive effect of overconsumption that credit cards enable, which can have a negative impact on the economy. TIETP could spur consumption with the expectation of tax cuts (seemingly very marginal but such cuts nevertheless lower the cost of the expenditure) and even more with the credit provided by credit cards. According to a survey conducted by the Korea Institute of Public Finance (2016, p.209), $31.3 \%$ of respondents selected the ability to pay without having the cash at hand as the first reason they use credit cards; $16.6 \%$ selected the convenience of payment without charges; $13.2 \%$ cited various rewards provided by credit card companies; $12.4 \%$ noted the tax deduction; $10.7 \%$ appreciated the possibility of installment payments; $10.1 \%$ opted for credit cards because of the possibility of paying without having a balance in the account. Tax incentives for making payments using debit cards or electronically traceable cash receipts may thus have fewer distortive effects on consumption and saving choices but relatively bigger substitution effects between nontraceable and traceable payments. Korea experienced the negative effect of overconsumption in the early stages of TIETP. Credit card transactions in Korea skyrocketed

46. "Lowering Credit Card Fees by 1-2\%," Mail Economy, September 11, 1999; "Government Calls for Lowering Credit Card Fees," Mail Economy, December 18, 1999; "Credit Card Fees, Maximum 10\% Lowered Within This Year," Dong-a Ilbo, December 17, 1999. 
between 1999 and 2002 after the introduction of TIETP, as shown in figure 3. While such a drastic increase in credit card transactions contributed to broadening the tax base to a great extent, overconsumption based on credit facilitated by credit cards put the Korean economy under tremendous stress. It is believed that TIETP coupled with deregulation of the credit card business, credit companies' reckless issuance of credit cards, and lax credit controls caused widespread credit-card-debt defaults and led to the collapse of at least one credit card company during 2002-2003. In response to this negative effect of TIETP, the Korean government in 2003 increased the deduction rate of TIETP for debit card transactions from $20 \%$ to $30 \%$ to induce consumers to use debit cards instead, while maintaining the deduction rate for credit card transactions. In addition, electronically traceable cash receipts were introduced in 2005 . These measures shifted a substantial portion of credit card transactions to debit cards or electronically traceable cash receipt transactions.

Seventh, given that tax deductions unevenly benefit higher income deciles over others, under the progressive personal income tax structure, tax credits as a form of TIETP are worth reviewing as a policy alternative. As mentioned, although Korea's TIETP has net positive effects on the GINI coefficient due to the tax-broadening effect, tax deductions have also had regressive effects of tax deductions.

Lastly, it should be admitted that TIETP broadens the tax base by taking advantage of tax incentives. TIETP provides a tax relief, which, like other tax incentives, has a lock-in effect. Many discussions conclude that TIETP should be repealed because it has not broadened the business income tax base enough; nonetheless, TIETP remains in place in Korea because wage and salary earners have a vested interest in it. Furthermore, it is not clear if business income would continue to be reported honestly if TIETP were withdrawn. Given these questions, further research may be needed to support a definitive conclusion that TIETP has actually enhanced voluntary compliance and changed taxpayers' behavior for good.

One of the most important findings is the estimation of revenue and distributional effects based on counterfactual analyses and simulations. However, we have not considered behavioral changes in taxpayers, although that does not seem to be noticeably large. But our not having explored this aspect may be a shortcoming and so it would be desirable to introduce a utility maximization model to address it. 


\section{REFERENCES}

Ainsworth, R. T., \& Hengartner, U. 2009. Quebec's sales recording module (SRM): Fighting the zapper, phantomware, and tax fraud with technology. Canadian Tax Journal/Revenue Fiscale Canadienne 57(4): 715-761.

A. T. Kearney, VISA, \& Schneider, F. 2009. The shadow economy in Europe: Using payment systems to combat the shadow economy. www.atkearney.com/documents/10192/1f89864d-903f-4683-b6e4-df57e223a4d7.

A. T. Kearney, VISA, \& Schneider, F. 2013. The shadow economy in Europe: 2013. www.atkearney.com/documents/10192/1743816/The+Shadow+Economy+in+Europe+2013.pdf.

Awasthi, R., \& Engelschalk, M. Forthcoming. Chasing shadows: Tax strategies to tackle the shadow economy. World Bank Policy Research Working Paper, World Bank, Washington, DC.

Beretta, E. 2014. The irreplaceability of cash and recent limitations on its use: Why Europe is off the track. Paper presented at "The Usage, Costs and Benefits of Cash Revisited" Conference, Deutsche Bundesbank, Dresden, September 15-18.

Choi, H. S., Park, S. O., \& Kim, Y. K. 2013. Tax policy recommendations for the normalization of the underground economy. Korean Journal of Taxation Research 30(4): 9-29.

Commission of the European Communities, International Monetary Fund, Organisation for Economic Co-operation and Development, United Nations, and World Bank. 1993. System of national accounts 1993. Brussels/Luxembourg, New York, Paris, Washington, DC.

Dekker, H., Oranje, E., Renooy, P., Rosing, F., \& Williams, C. 2010. Joining up in the fight against undeclared work in Europe. Regioplan Policy Research, Regioplan, Amsterdam.

European Central Bank. 2014a. Opinion of the European Central Bank on limitations on cash payments. CON/2014/4. January 17. https://www.ecb.europa.eu/ecb/ legal/pdf/en_con_2014_4_f_sign.pdf.

European Central Bank. 2014b. Opinion of the European Central Bank on the limitations on cash payments and receipts. CON/2014/37. May 22. https://www.ecb. europa.eu/ecb/legal/pdf/en_con_2014_37_f_sign.pdf.

European Commission. 1998. Communication of the commission on undeclared work. April 7. COM(98)-219.

European Commission. 2013. Developing personal and household services in the EU: A focus on housework activities. Brussels: European Commission. 
Feld, L. P., \& Schneider, F. 2010. Survey on the shadow economy and undeclared earnings in OECD countries. German Economic Review 11(2): 109-149.

Friedman, E., Johnson, S. \& Kaufmann, D. 2000. Dodging the grabbing hand: The determinants of unofficial activity in 69 countries. Journal of Public Economics 76(3): 459-493.

Gërxhani, K. 2004. The informal sector in developed and less developed countries: A literature survey. Public Choice 120(3-4): 267-300.

Hurst, E., Li, G., \& Pugsley, B. 2014. Are household surveys like tax forms? Evidence from income underreporting of the self-employed. Review of Economics and Statistics 96(1): 19-33.

Jang, C. 1997. Establishing a basic tax data system. Seoul: Korea Institute of Public Finance.

Jensen, J., \& Wőhlbier, F. 2012. Improving tax governance in EU member states: Criteria for successful policies. Brussels: European Commission.

Irish Revenue. 2015. Cash registers and the obligation to maintain proper books and records to determine tax liability or entitlement to deductibility. http:/www.revenue.ie/en/tax/vat/leaflets/cash-registers.html.

Korea Institute of Public Finance. 2016. In-depth analysis of tax incentives: Tax deductions on credit card payments. Seoul.

Lyssiotou, P., Pashardes, P., \& Stengos, T. 2004. Estimates of the black economy based on consumer demand approaches. Economic Journal 114(497): 622-640.

Martinez-Lopez, D. 2012. The underreporting of income by self-employed workers: A new interpretation with Spanish data. Unpublished manuscript. Department of Economics, University Pablo de Olavide, Seville.

Ministry of Strategy and Finance \& Korea Development Institute. 2011. Modularizing Korea's development process: Innovations in tax policy. Seoul.

National Tax Service. 1988-2015. Statistical yearbook of national taxes. Seoul.

Naritomi, J. 2015. Consumers as tax auditors. London School of Economics. http:// scholar.harvard.edu/jnaritomi/research.

Nwankwo, O., \& Eze, O. R. 2013. Electronic payment in cashless economy of Nigeria: Problems and prospect. Journal of Management Research 5(1): https://doi. org/10.5296/jmr.v5i1.2650. www.macrothink.org/journal/index.php/jmr/article/ view/2650/2434.

OECD (Organization for Economic Co-operation and Development). 2013. Electronic sales suppression: A threat to tax revenues. www.oecd.org/ctp/crime/ElectronicSalesSupression.pdf.

OECD, Forum of Tax Administration: Compliance Subgroup. 2009. Developments in VAT compliance management in selected countries. https://www.oecd.org/tax/ 
administration/43728444.pdf.

OECD, International Monetary Fund, International Labour Organisation, and Interstate Statistical Committee of the Commonwealth of Independent States. 2002. Measuring the non-observed economy: A handbook. Paris: OECD.

Perry, G. E., Maloney, W. F., Arias, O. S., Fajnzylber, P. I., Mason, A. D., \& Saavedra-Chanduvi, J. 2007. Informality exit and exclusion. World Bank Group. http://siteresources.worldbank.org/INTLAC/Resources/CH0.pdf.

Pissarides, C. A., \& Weber, G. 1989. An expenditure-based estimate of Britain's black economy. Journal of Public Economics 39(1): 17-32.

Rogoff, K. S. 2016. The curse of cash. Princeton, NJ: Princeton University Press.

Rruhn, M. 2008. License to sell: The effect of business registration reform on entrepreneurial activity in Mexico. Review of Economics and Statistics 93(1): 382386.

Schneider, F., Buehn, A., \& Montenegro, C. 2010. New estimates for the shadow economies all over the world. International Economic Journal 24(4): 443-461.

Singh, A., Jain-Chandra, S., \& Mohommad, A. 2012. Inclusive growth, institutions, and the underground economy. IMF Working Paper WP/12/47, IMF, Washington, DC.

Song, H., \& Sung, M. J. 2012. Effects of personal income tax deduction on credit card use. Korean Journal of Public Finance 5(2): 157-194.

Stankevičius, E., \& Vasiliauskaite, A. 2014. Tax burden level leverage on size of the shadow economy: Cases of EU countries, 2003-2013. Rocedia: Social and Behavioral Sciences 156: 548-552.

Sung, M. J. 1999. Global income tax and VAT evasion in Korea. Research Report 99-05. Seoul: Korea Institute of Public Finance.

- 2008. Business income reporting rate and related tax evasion. Korean Journal of Public Finance 1(3): 155-188.

Wan, J. 2010. The incentive to declare taxes and tax revenue: The lottery receipt experiment in China. Review of Development Economics 14(3): 611-624.

Wangen, K. R. 2005. An expenditure-based estimate of Britain's black economy revisited." Discussion Papers No. 414, Research Department, Statistics Norway, Oslo.

Williams, C. C. 2009. Measures to tackle undeclared work in 27 European countries. http://works.bepress.com/colin_williams/2/download.

Williams, C. C., \& Schneider, F. 2016. Measuring the global shadow economy: The prevalence of informal work and labour. Northampton, MA: Edward Elgar Publishing. 


\section{Appendix 1. Household Income and Expenditure Survey}

The Household Income and Expenditure Survey is collected, compiled, and released by Statistics Korea. Thousands of households are included in each layer of cross-sectional sample, up to roughly 10,000. Every household is repeatedly surveyed for three to five years on a monthly basis, and results are compiled and released on a quarterly basis. Households are identifiable by unique identification numbers preassigned by Statistics Korea, allowing monthly or quarterly information to be easily convertible into annual values household by household. Households in the sample are replaced with new households on a regular basis after three to five years of participation. However, any number of households typically will be replaced sooner, particularly when they become unable to be surveyed for any reason, such as movement abroad or movement without notice, abrupt refusal to participate, demise, divorce, and so on.

Descriptive statistics for the 2014 Household Income and Expenditure Survey are reported in the following table.

Table A-1 Household Income and Expenditure Survey 2014 Descriptive Statistics (Unit: thousand )

\begin{tabular}{l|r|r|r|r}
\hline & Average & Standard Dev. & Maximum & \multicolumn{1}{|c}{ Minimum } \\
\hline Age of Household Head & 52.34 & 14.03 & 95 & 17 \\
\hline $\begin{array}{l}\text { Household Size (Number of } \\
\text { Family Members) }\end{array}$ & 2.75 & 1.26 & 8 & 1 \\
\hline Number of Income Earners & 1.25 & 0.88 & 6 & 0 \\
\hline Market Income & 43,305 & 31,490 & 300,868 & 0 \\
\hline Gross Income & 48,088 & 30,254 & 300,354 & 0 \\
\hline Disposable Income & 43,858 & 25,996 & 289,418 & 0 \\
\hline Consumption Expenditure & 26,534 & 16,896 & 213,639 & 925 \\
\hline $\begin{array}{l}\text { Personal Income Tax for } \\
\text { Wage/Salary and Business }\end{array}$ & 1,775 & 3,358 & 55,607 & 0 \\
Income & 204 & 391 & 5,686 & 0 \\
\hline Property Tax Burden & 2,432 & 2,411 & 43,561 & 0 \\
\hline Social Security Contributions & 2,421 & 8,025 & 104,824 & 0 \\
\hline Private Transfer Income & 2,362 & 6,312 & 86,653 & 0 \\
\hline Public Transfer Income & & & &
\end{tabular}

Note: The 2014 Household Income and Expenditure Survey catalogues information from 4,904 households. It is annualized from quarterly variables. 


\section{Appendix 2. Methodology of Personal Income Tax Estimation}

Personal income tax burdens were estimated using the annualized Household Income and Expenditure Survey data set and the Korean national tax simulator program developed by the Korea Institute of Public Finance, a tax liability calculator similar to TAXSIM, used by the National Bureau of Economic Research.

Personal income tax burdens were estimated separately for wage and salary income earners and for self-employed business income earners. We calculated the personal income tax burdens of wage and salary income earners directly with the tax simulator program, using the raw income data in Household Income and Expenditure Survey, under the assumption that wage and salary income earners reported their true income honestly in the survey. However, given the tendency of the self-employed to underreport their income even in anonymous surveys, we drew on Sung's (1999) methodology to modify income data reported in the Household Income and Expenditure Survey by the self-employed for personal income tax calculations. Further, we assumed that all business income earners were risk neutral and, as a result, that their tax compliance rates were all the same. First, the real business income of each household was estimated by comparing income-consumption patterns between wage and salary earners and the self-employed, as is done by Pissarides and Weber (1989). Second, the business income reporting ratio $(\beta)$ in the following formula was estimated through the iterative method.

$$
\frac{\sum P I T(\beta \times R B I)}{\left(\beta \times \sum R B I\right)}=\frac{P I T_{\text {rev }}}{N}
$$

Where $\beta$ is the ratio $(1<\beta<1)$ of business income reported to the National Tax Service to real business income (which is estimated in the first step); $P I T(\beta \times R B I)$ is personal income tax burden of reported business income $(\beta \times R B I)$ of each household calculated by the tax simulator program; $P I T_{r e v}$ is the total personal income tax revenue from business income given in the Statistical Yearbook of National Tax (National Tax Service 2015); and N is the total number of personal income tax taxpayers of business income given in the Statistical Yearbook of National Tax (National Tax Service 2015). Lastly, the personal income tax burdens of business income per household in each decile were estimated with the tax simulator program using the real business income, business income reporting ratio $(\beta)$, and demographic data in Household Income and Expenditure Survey. 